\title{
GRANITOID MAGMATISM IN THE NORTH OF THE URALS: U-Pb AGE, EVOLUTION, SOURCES
}

\author{
O.V. Udoratina $\circledast^{1,2 \bowtie}$, K.V. Kulikova $\oplus^{1}$, A.S. Shuyskiy ${ }^{1}{ }^{1}$, A.A. Soboleva ${ }^{1}{ }^{1}$, \\ V.L. Andreichev ${ }^{1}{ }^{1}$, I.I. Golubeva ${ }^{1}{ }^{1}$, V.A. Kapitanova ${ }^{1}{ }^{1}$
}

\author{
${ }^{1}$ Institute of Geology of Komi Science Center, Ural Branch of the Russian Academy of Sciences, 54 Pervomaiskaya St, \\ Syktyvkar 167982, Russia \\ ${ }^{2}$ Tomsk State University, 36 Lenin Ave, Tomsk 634050, Russia
}

ABSTRACT. This work presents the summarization of U-Pb (SIMS, TIMS) zircon dates and petrogeochemical signatures of granitoids of the north of the Urals (Polar, Subpolar, and Northern Urals) obtained over the last decade. Granite melts were formed from melting of different substrates, highly heterogeneous in composition and age, at all geodynamic stages distinguished in the studied area. Preuralides include island arc-accretionary (735-720 Ma, 670 Ma), collisional (650-520 Ma), and rift-related (520-480 Ma) granitoids. Uralides includes primitive island-arc granitoids (460-429 Ma), mature island-arc granitoids (412-368 Ma), early collisional (360-316 Ma) and late collisional (277-249 Ma) granitoids. As a result, the general trend of variations of oxygen $\left(\delta^{18} \mathrm{O}_{\mathrm{Zrn}}, \% 0\right)$, neodymium $\left(\varepsilon \mathrm{Nd}_{(\mathrm{t}) \mathrm{wr}}\right)$, and hafnium $\left(\varepsilon \mathrm{Hf} \mathrm{ft}_{\mathrm{Zrn}}\right)$ isotope compositions identified in time. Mantle isotope compositions $\left(\delta^{18} \mathrm{O}_{\mathrm{Zrn}}(+5.6), \varepsilon \mathrm{Nd}_{(\mathrm{t}) \mathrm{wr}}(+1.7), \varepsilon \mathrm{Hf}_{(\mathrm{t}) \mathrm{Zrn}}(+8.7 \ldots+10.6)\right), \mathrm{com}-$ mon for island arc granitoids (Preuralides) are changed by crustal-mantle ones $\left(\delta^{18} \mathrm{O}_{\mathrm{zrn}}(+7.2 \ldots+8.5), \varepsilon N d_{(t) w r}(-4.8 \ldots+1.8)\right.$, $\varepsilon \mathrm{Hf}_{(\mathrm{t}) \mathrm{Zn}}(+2.1$ to +13$\left.)\right)$, typical of collisional granites. According to this, the crustal matter played a significant role during the formation of the latter. The crustal-mantle isotope compositions are changed by the mantle ones, characteristic of rift-related $\left(\delta^{18} \mathrm{O}_{\mathrm{Zrn}}(+4.7 \ldots+7), \varepsilon \mathrm{Nd}_{(\mathrm{t}) \mathrm{wr}}(+0.7 \ldots+5.6), \varepsilon \mathrm{Hf}_{(\mathrm{t} \mathrm{Zzr}}(-2.04 \ldots+12.5)\right)$ and island-arc $\left(\right.$ Uralides; $\delta^{18} \mathrm{O}_{\mathrm{Zrn}}(+4.2 \ldots+5.7)$, $\left.\varepsilon \mathrm{Nd}_{(\mathrm{t}) \mathrm{wr}}(+4.1 \ldots+7.4), \varepsilon \mathrm{Hf}_{(\mathrm{t}) \mathrm{Zrn}}(+12 \ldots+15.2)\right)$ granitoids.

KEYWORDS: isotope-geochemical signatures of granitoids; the whole-rock Nd isotope compositions; 0; Hf isotope compositions of zircons; U-Pb age; north of the Urals; Polar; Subpolar; and Northern Urals

FUNDING: The studies were started as part of the projects 09-C-5-1017, 12-C-5-1024 (0.V. Udoratina), 15-18-5-40 (V.L. Andreichev), 15-18-5-57, 18-5-5-46 (K.V. Kulikova), and also received under the Agreement on Scientific Collaboration of 12.12.2008 and 15.01.2012 with the Department of Geology and Environmental Sciences, School of Earth, Stanford University (USA, E. Miller). At present, they are continuing within the framework of the state task of the Institute of Geology of Komi Science Center of the Ural Branch of the Russian Academy of Sciences (project No AAAA-A17-117121270035-0) and are partially financially supported by the Government of the Russian Federation (project No 14.Y26.31.0012, R. Ernst).

\section{RESEARCH ARTICLE}

Correspondence: Oksana V. Udoratina, udoratina@geo.komisc.ru
Received: June 6, 2020

Revised: December 2, 2020 Accepted: December 10, 2020

FOR CITATION: Udoratina O.V., Kulikova K.V., Shuyskiy A.S., Soboleva A.A., Andreichev V.L., Golubeva I.I., Kapitanova V.A., 2021. Granitoid magmatism in the north of the Urals: U-Pb age, evolution, sources. Geodynamics \& Tectonophysics 12 (2), 287-309. doi:10.5800/GT2021-12-2-0525 


\title{
ГРАНИТОИДНЫЙ МАГМАТИЗМ СЕВЕРА УРАЛА: U-РЬ ВОЗРАСТ, ЭВОЛЮЦИЯ, ИСТОЧНИКИ
}

\author{
О.В. Удоратина ${ }^{1,2}$, К.В. Куликова ${ }^{1}$, А.С. Шуйский ${ }^{1}$, А.А. Соболева ${ }^{1}$, \\ В.Л. Андреичев ${ }^{1}$, И.И. Голубева ${ }^{1}$, В.А. Капитанова ${ }^{1}$
}

\author{
${ }^{1}$ Институт геологии ФИЦ Коми НЦ УрО РАН, 167982, Сыктывкар, ул. Первомайская, 54, Россия \\ ${ }^{2}$ Томский государственный университет, 634050, Томск, пр-т Ленина, 36, Россия
}

АНнотАция. Проведено обобщение полученных в последнее десятилетие U-Pb цирконовых возрастов (SIMS, TIMS) и петрогеохимических характеристик гранитоидов севера Урала (Полярный, Приполярный и Северный Урал). Гранитные расплавы формировались на всех выделенных для этого региона геодинамических стадиях из крайне неоднородных по составу и возрасту субстратов. Доуралиды: островодужные примитивной островной дуги (735-720 млн лет), аккреционные (670 млн лет), коллизионные (650-520 млн лет), рифтогенные (520-480 млн лет). Уралиды: островодужные примитивной островной дуги (460-429 млн лет), островодужные зрелой островной дуги (412-368 млн лет), коллизионные ранние (360-316 млн лет), коллизионные поздние (277-249 млн лет). Выявлена общая тенденция изменения во времени изотопных составов кислорода $\left(\delta^{18} \mathrm{O}_{\mathrm{zrn}} \%\right.$ \% $)$, неодима $\left(\varepsilon \mathrm{Nd}_{(\mathrm{t}) \mathrm{wr}}\right)$ и гафния $\left(\varepsilon \mathrm{Hf}_{(\mathrm{t}) \mathrm{Zrn}}\right)$. Мантийные значения $\left(\delta^{18} \mathrm{O}_{\mathrm{zrn}}(+5.6), \varepsilon \mathrm{Nd}_{(\mathrm{t}) \mathrm{wr}}(+1.7), \varepsilon \mathrm{Hf}_{(\mathrm{t}) \mathrm{Zrn}}(+8.7 \ldots+10.6)\right)$, типичные для островодужных (доуралиды) гранитов, меняются на корово-мантийные $\left(\delta^{18} \mathrm{O}_{\mathrm{zrn}}(+7.2 \ldots+8.5), \varepsilon \mathrm{Nd}(\mathrm{t}) \mathrm{wr}(-4.8 \ldots+1.8)\right.$, $\left.\varepsilon \mathrm{Hf}_{(\mathrm{t}) \mathrm{Zrn}}(+2.1 \ldots+13)\right)$, характерные для коллизионных гранитов, в которых прослеживается большее влияние корового вещества при формировании расплавов, и далее меняются на значения с мантийными характеристиками, которые присущи рифтогенным $\delta^{18} \mathrm{O}_{\mathrm{zrn}}(+4.7 \ldots+7), \varepsilon \mathrm{Nd}_{(\mathrm{t}) \mathrm{wr}}(+0.7 \ldots+5.6), \varepsilon \mathrm{Hf}_{(\mathrm{t}) \mathrm{Zrn}}(-2.04 \ldots+12.5)$ и островодужным (уралиды) $\delta^{18} \mathrm{O}_{\mathrm{zrn}}(+4.2 \ldots+5.7), \varepsilon \mathrm{Nd}_{(\mathrm{t}) \mathrm{wr}}(+4.1 \ldots+7.4), \varepsilon \mathrm{Hf}_{(\mathrm{t}) \mathrm{Zrn}}(+12 \ldots+15.2)$ гранитоидам.

КЛЮЧЕВЫЕ СЛОВА: изотопно-геохимические характеристики гранитоидов; изотопный состав неодима пород; изотопный состав кислорода цирконов; изотопный состав гафния цирконов; U-Pb возраст; север Урала; Полярный; Приполярный; Северный Урал

ФИНАНСИРОВАНИЕ: Исследования были начаты в рамках проектов 09-С-5-1017, 12-С-5-1024 (О.В. Удоратина), 15-18-5-40 (В.Л. Андреичев), 15-18-5-57, 18-5-5-46 (К.В. Куликова), также использованы данные, полученные в рамках Соглашения о научном сотрудничестве от 12.12.2008 г. и 15.01.2012 г. с Департаментом геологии и экологических наук Школы наук о Земле Стэнфордского университета (США, Э. Миллер). В настоящее время они продолжаются в рамках государственного задания Института геологии им. Н.П. Юшкина Коми НЦ УрО РАН ГР АААА-А17117121270035-0 и частично поддерживаются Правительством Российской Федерации (проект 14.Y26.31.0012, Р. Эрнст).

\section{INTRODUCTION}

The north of the Urals is geographically divided, from north to south, into the Polar, Subpolar, and Northern Urals and is bounded by Mt. Konstantinov Kamien from the north and Mts. Kosvinsky Kamien and Konzhakovsky Kamien from the south (Fig. 1, a, b).

Granitoids of the north of the Urals have always been the subject of an increased focus, which is reflected in the extensive list of literature [Okhotnikov et al., 1985; Makhlaev, 1996; Goldin et al., 1999; Makhlaev et al., 2005; Kuznetsov et al., 2005a, 2005b, 2007; Andreichev, 1999, 2010; Puchkov, 2010; Melgunov et al., 2010; Soboleva, Udoratina, 2010]. Even recently, their age and formation conditions are the subject of discussion. Due to geological surveying and thematic studies performed in the north of the Urals over the past decade, quite many works present geochronological and isotope-geochemical data on granitoid massifs have been published by authors of the present paper and other researchers. The present report summarizes all these materials.

As evidenced from the previous summaries, differences between granitoids from the Central Uralian and East Uralian megazones in the north of the Urals have long been known.
The differences between granites of the Subpolar Urals in terms of chemical and mineral composition were interpreted to connect with variations in the conditions during their emplacement. Some researchers [Goldin et al., 1981; Shteinberg, Vigorova, 1976] subdivided granites to "dry" and "hydrous" varieties. The dry granites, confined to the western part of the granite distribution area, show that they were crystallized under the hypabyssal conditions. The "hydrous" ones, distributed eastward, are attributed to deeper sources.

The systematics of granitoids of the north of the Urals based on studying their protoliths was proposed by L.V.Makhlaev [Makhlaev, 1996]. Using Chappell's compositional-genetic classification [Chappell, White, 1974], Makhlaev subdivided granitoids in I- and A-types, considering the reason for their difference in the compositional heterogeneity of the granite-producing substratum. The protoliths of differentiated calc-alkaline I-type granitoids were apo-mafic metamorphic rocks. The A-type leucogranites of the normal and higher alkalinity were formed due to the melting of the granulite and granite-gneissic substratum. This conclusion is in accordance with a geological-geophysical model of 

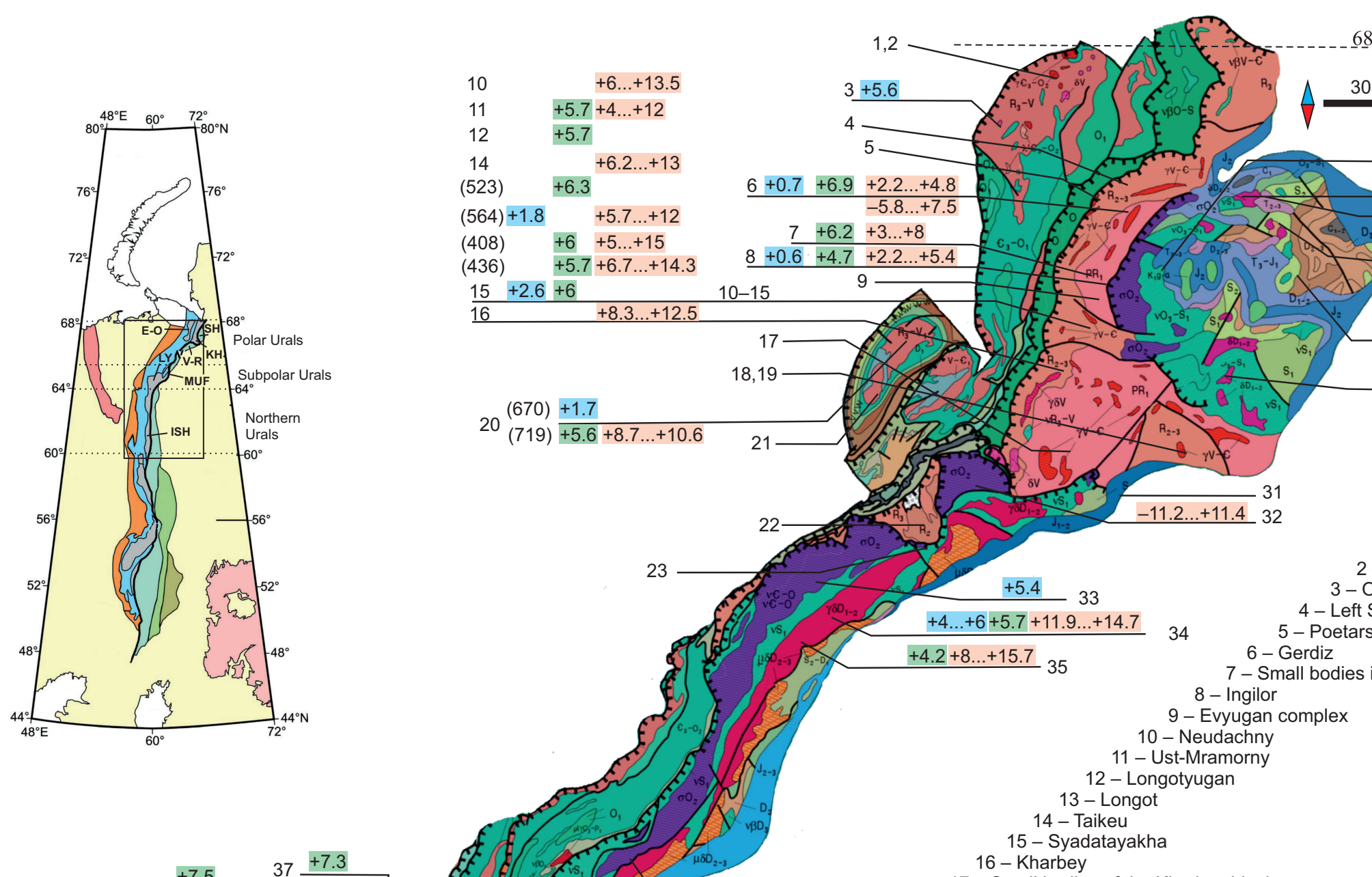

1 - Section West B -

Left Shchuchye (Syadatayakha)

16 - Kharbey

18 - Sandibey

20 - Enganepe (melange Manyukuyakha)

21 - Yuzhny
22 - Small bodies of the Kharamatalou

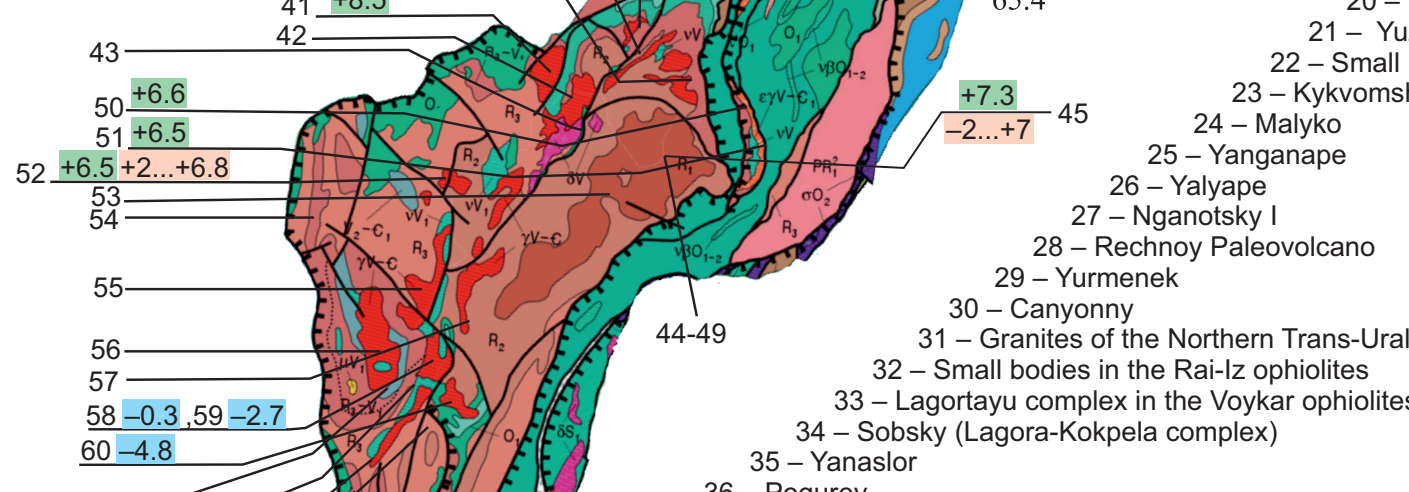

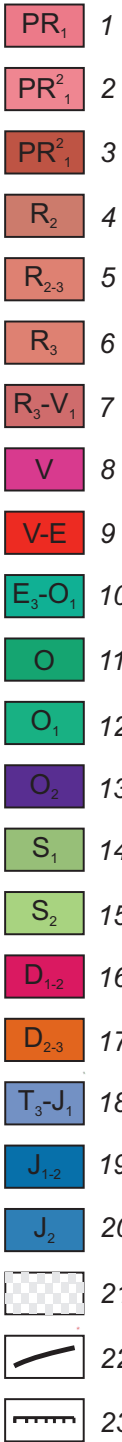

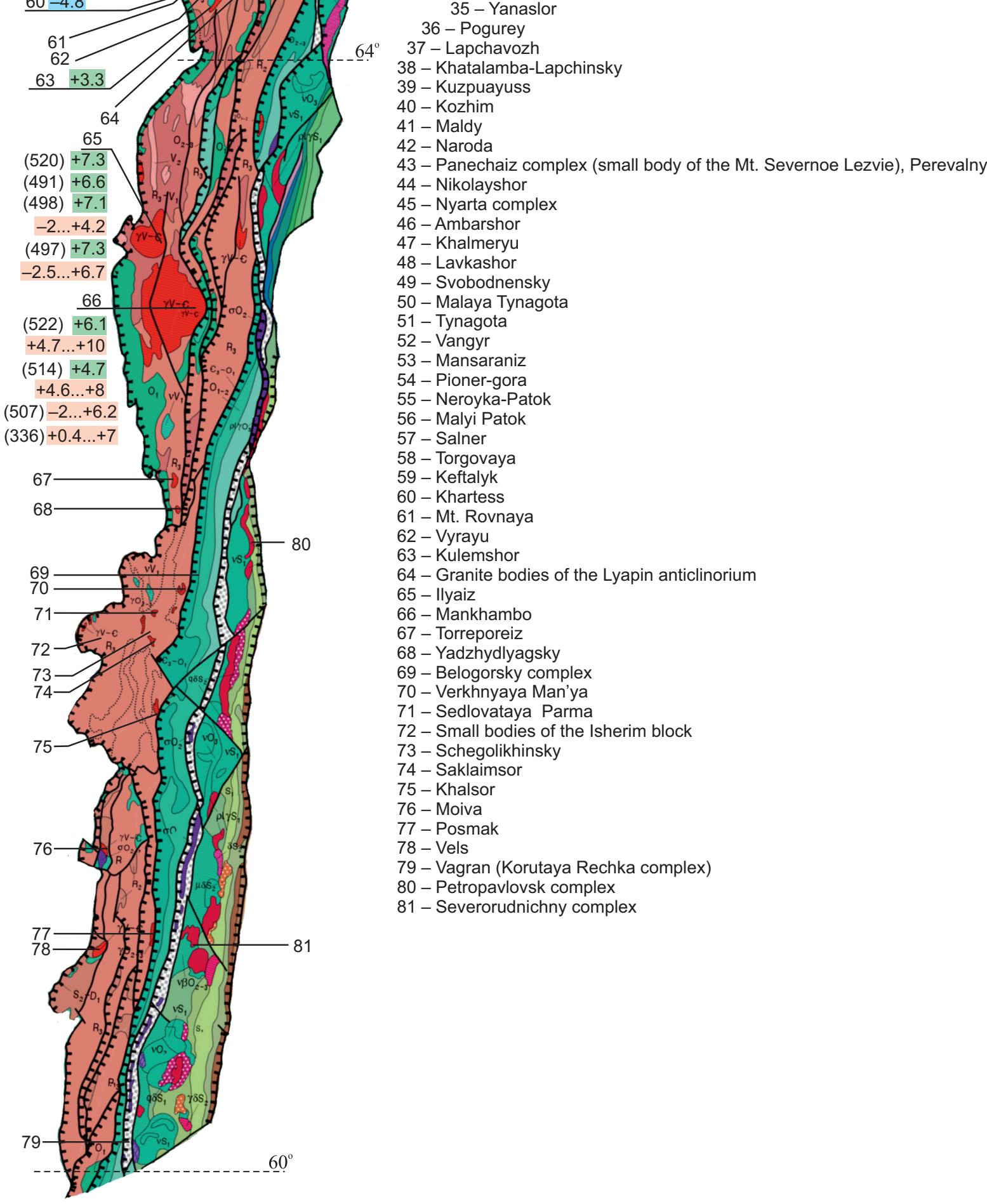


Fig. 1. Locality of the study area on the geological-tectonic map of the Urals [Puchkov, 2010; Estrada et al., 2012 (with amendments)] (a). 1 - Timan; 2 - Pre-Urals Foreland basin; 3 - West Uralian megazone; 4 - Central Uralian megazone; 5 - Magnitogorsk - Tagil megazone; 6 - East Uralian megazone; 7 - Transuralian megazone; 8 - Permian, Mesozoic, Cenozoic; 9 - Kazakhstan Craton. E-0 - Enganepe and Ochenyrd uplifts, KH - Kharbey block, SH - Schuchinsky subzone, V-R - Voykar - Rai-Iz subzone, LY - Lyapin anticlinorium, ISH Isherim block, MUF - Main Uralian Fault. The study area is shown by a rectangle. Northern Urals (58.45-64 N), Subpolar Urals (64$\left.65.4^{\circ} \mathrm{N}\right)$, Polar Urals $\left(65.4-68.30^{\circ} \mathrm{N}\right)$.

The fragment of the 1:2500000 geological map of the north of the Urals [Petrov, 2016] $(b) .1$ - Lower Proterozoic; 2 - upper Lower Proterozoic; 3 - upper Lower Proterozoic (high-grade metamorphic); 4 - Middle Riphean; 5 - Middle-Upper Riphean; 6 - Upper Riphean; 7 - Upper Riphean - Lower Vendian; 8 - Vendian; 9 - granites, plagiogranites, quartz diorites; 10 - Upper Cambrian - Lower Ordovician; 11 - Ordovician; 12 - Lower Ordovician; 13 - peridotites and dunites; 14 - Lower Silurian; 15 - Upper Silurian; 16 - diorites, granodiorites, quartz diorites; 17 - Middle - Upper Devonian; 18 - Upper Triassic - Lower Jurassic; 19 - Lower - Middle Jurassic; 20 - Middle Jurassic; 21 - tectonic mélange; 22 - MUF; 23 - geological boundaries. Color designations: $\varepsilon \mathrm{Nd}_{(\mathrm{t}) \mathrm{wr}}-\mathrm{blue}, \delta^{18} \mathrm{O}_{\mathrm{Zrn}}-\mathrm{green}_{\mathrm{r}} \varepsilon \mathrm{Hf}$ in case of a number of values, the age (Ma) is given. Granite massifs (complexes) of the north of the Urals (1-81) - the name of a massif (section West Borzovsky ... Severorudnichny complex) (c).

Рис. 1. Положение района исследований на геолого-тектонической карте Урала (по [Puchkov, 2010; Estrada et al., 2012, с изменениями]) (a).

1 - Тиман; 2 - Предуральский краевой прогиб; 3 - Западно-Уральская мегазона; 4 - Центрально-Уральская мегазона; 5 - Тагило-Магнитогорская мегазона; 6 - Восточно-Уральская мегазона; 7 - Зауральская мегазона; 8 - пермские, мезозойские, кайнозойские отложения; 9 - Казахстанский кратон; Е-О - поднятия Енганепэ и Оченырд, КН - Харбейский блок, SH - Щучьинская зона, V-R - Войкаро-Райизская зона, LY - Ляпинский антиклинорий, ISH - Ишеримский блок, MUF - главный уральский разлом (надвиг), выделенная зона - район исследований. Северный Урал (58.45-64 N), Приполярный Урал (64-65.4 N), Полярный Урал $\left(65.4-68.30^{\circ} \mathrm{N}\right)$.

Фрагмент геологической карты севера Урала 1:2500000 [Petrov, 2016] (b). 1 - нижний протерозой; 2 - верхняя часть нижнего протерозоя; 3 - верхняя часть нижнего протерозоя (высокометаморфизованные); 4 - средний рифей; 5 - средний - верхний рифей; 6 - верхний рифей; 7 - верхний рифей - нижний венд; 8 - венд; 9 - граниты, плагиограниты, кварцевые диориты; 10 - верхний кембрий - нижний ордовик; 11 - ордовик; 12 - нижний ордовик; 13 - перидотиты и дуниты; 14 - нижний силур; 15 - верхний силур; 16 - диориты, гранодиориты, кварцевые диориты; 17 - средний - верхний девон; 18 - верхний триас нижняя юра; 19 - нижняя - средняя юра; 20 - средняя юра; 21 - меланж тектонический; 22 - ГУР; 23 - геологические границы. Цветом показаны значения $\varepsilon \mathrm{Nd}_{(\mathrm{t}) \mathrm{wr}}-$ синий, $\delta^{18} \mathrm{O}_{\mathrm{zrn}}$ - зеленый, $\varepsilon \mathrm{Hf}_{(\mathrm{t} Z \mathrm{Zn}}-$ розовый, при наличии нескольких данных справа вынесен возраст (млн лет). Гранитные массивы (комплексы) севера Урала (1-81) - название массива (уч. Зап. Борзовский ... северорудничный комплекс) $(c)$.

the deep structure of the Central Uralian megazone [Berland, 1982]. In terms of density features, the crystalline basement of the latter is close to metamafic rocks in the western zone and granite-gneisses in the eastern one. Massifs, composed of I-type granites, are confined to the west zone; the A-type granites dominate in the east zone.

The typification of granitoids and the combination of petrogeochemical signatures with $\mathrm{U}-\mathrm{Pb}$ ages brought researchers [Makhlaev, 1996; Soboleva et al., 2005a, 2015; Andreichev, 2010; Soboleva, Udoratina, 2010] to understanding the evolution of granitoid magmatism in the north of the Urals and accepting the fact that granitoids of different types could often form simultaneously. The recent isotopegeochemical signatures $\left(\mathrm{O}_{\mathrm{zrn}}, \mathrm{Sm}-\mathrm{Nd}_{\mathrm{wr}}, \mathrm{Lu}-\mathrm{Hf} \mathrm{zrn}_{\mathrm{rrn}}\right)$ provide insight into the understanding of the primary protoliths of granite melts and their characteristics, as well as the evolution of source rocks and melts in the studied region.

We have taken only U-Pb (SIMS, and TIMS) age of zircons from granitoid massifs into account. Also, our new $\delta^{18} \mathrm{O}_{\text {zrn }} \%$, $\varepsilon \mathrm{Hf}_{(\mathrm{t}) Z \mathrm{rn}}$, and $\varepsilon \mathrm{Nd}_{(\mathrm{t}) w r}$ data are used. For our work, we have used our and published U-Pb (SIMS, TIMS) isotope ages (210) of zircons from 81 massifs of the north of the Urals, obtained mainly over the past decade using the techniques described in the primary publications. To construct different diagrams, we have used our own and published data on the chemical composition of dated rocks and contents of rare, rare-earth, and trace elements.
The petrogeochemical, geochronological, and isotopegeochemical data on granitoids from the southernmost parts of the Southern Urals, Kanin-Timan Range, and the basement of the Pechora syneclise were not taken into consideration.

This work aims at confirming reference boundaries previously established for the Preuralides and Uralides, analyzing the change of granite melt sources based on petrogeochemical and isotope-geochemical signatures of granitoids. The problems to be considered in the given work are as follows: (1) analysis of the available U-Pb dates of single zircon grains obtained over the past decade, (2) analysis of petrogeochemical features of dated granitoids, (3) analysis of the change of the granite melt sources based on newly obtained isotope-geochemical characteristics $\left(\mathrm{O}_{\mathrm{zrn}}\right.$, $\mathrm{Hf}_{\mathrm{Zrn}}, \mathrm{Nd}_{\text {whole-rock }}$ ), and (4) geodynamic interpretation using $\mathrm{U}-\mathrm{Pb}$, petrogeochemical, and isotope-geochemical data on granitoids.

\section{GEOLOGICAL POSITION OF GRANITES IN THE NORTH OF THE URALS}

The Uralian collisional orogen in the entire Urals and the north of the Urals, in particular, is composed of the complexes of the East European Craton (Laurussia), island arcs, and fragments of ophiolite complexes [Biske, 2019; Puchkov, 2010]. The Urals is geographically divided from south to north into the Southern, Middle, Northern, Subpolar, and Polar Urals. Structural megazones of the Urals (from west 
to east) (Fig. 1, a) are Pre-Urals Foreland basin, West Uralian, Central Uralian, Tagil-Magnitogorsk, East Uralian, and Transuralian megazones. The East Uralian and Transuralian megazones are overlain in the north by deposits of the Siberian Platform. The term East Uralian megazone is often used to refer to complexes (analogs) of the Tagil-Magnitogorsk megazone.

There are no granitoids in the north of the Urals, marking the development of the proper Uralian collisional orogen. The Uralian Orogen ("Uralides") is a young fold belt marking collisional events at the eastern margin of the former Laurussia continent during the Late Carbonaceous and Permian. At this, granitoids, marking the development of the earlier Timan (pre-Uralian) collision, are exposed in the north of the Urals, the Central Uralian megazone, the crystalline basement complexes of the Pechora Plate and Timan. The time of this collision is estimated at $550 \mathrm{Ma}$ [Kuznetsov et al., 2007]. Along with granitoids, the more ancient granite island arc complexes occur in the complexes of the Preuralides.

Preuralides (Timanides) and Uralides, two main structural stages, indicating two separate cycles of tectonic development, are distinguished in the geological structure of the Urals. They were first distinguished in the Southern Urals [Kheraskov, 1948] and extended later to the entire Urals [Kheraskov, Perfiliev, 1963]. Since that time, almost all researchers call them Preuralides (after N.P. Kheraskov) and Uralides. The pre-Ordovician formations are attributed to the lower structural stage; the Uralides, the Hercynian fold system of the Urals, refer to the upper stage. The term Baikalides is often used to designate the Preuralides. In recent years, the terms Protouralides and Timanides have appeared in publications, but they are all synonymous with the priority term Preuralides. Due to this, we have preferred to use the latter.

In the north of the Urals, granite massifs are concentrated in the Central Uralian and East Uralian (Tagil-Magnitogorsk) megazones. The Central Uralian megazone (Central Uralian Uplift, the axial zone of the Urals), located westward of the Main Uralian Fault (MUF), is composed of structural and compositional complexes of the Preuralides. The East Uralian megazone (Tagil-Magnitogorsk), located eastward of the MUF, are composed of complexes of the Uralides.

The complete section (from north to east) was described in the Polar Urals, where granitoids crop out in the Central Uralian (Enganepe, Ochenyrd, and Sob uplifts; Suppl. 1; Fig. 1, b, c, (1-23) and East Uralian (Suppl. 1; Fig. 1, c (24-36)) megazones. Most of the granitoid bodies in the Polar Urals are confined to the Central Uralian megazone (Suppl. 1; Fig. 1, b, c (37-64)). In the Northern Urals, granitoids occur in the Central Uralian (Suppl. 1; Fig. 1, b (65-79)) and the East Uralian (Suppl. 1; Fig. 1, b, c (80-81)) megazones.

The detailed description of granitoids (geological-structural position of granitoid massifs, petrographic, petrochemical, geochemical, isotope-geochemical, geochronological characteristics, and the geodynamic interpretations) is given in our publications and publications of other researchers (Suppl. 1; Fig. 1, c; references).
The series of the studied granite massifs include (1) small granitoid bodies (described by different researchers as granite-gneisses), developed among high-grade metamorphosed complexes of the Kharbey block of the Polar Urals (Suppl. 1; Fig. 1, b, c (7, 17, 22-23) and the Nyarta block of the Subpolar Urals (Suppl. 1; Fig. 1, b, c (44-49)); (2) "raremetal" granite massifs, which experienced superimposed metasomatic processes: massifs of the Taikeu group of the Polar Urals (Suppl. 1; Fig. 1, b, c (10-14)), Torgovaya-Kulemshor massif of the Subpolar Urals (Suppl. 1; Fig. 1, b, c (58, 63) ) and partially granitoids of the Mankhambo massif of the Northern Urals (Suppl. 1; Fig. 1, b, c (66)); and (3) structurally complex massifs; for example, Gerdiz (Suppl. 1; Fig. 1, b, c (6)), Ingilor of the Polar Urals (Suppl. 1; Fig. 1, b, c (8)) and the Naroda of the Subpolar Urals (Suppl. 1; Fig. 1, b, c (42)), Ilyaiz and Mankhambo in the Northern Urals (Suppl. 1; Fig. 1, b, c (65-66)). Granitoids of the northern and southern parts of the latter massifs are different in the type of the substratum, involved in melting and ages as often as not. Moreover, granitoids form a constituent part of gabbro-granite associations, and they are also observed among ophiolites of the Voykar and Shchuchiya zones of the Polar Urals.

\section{PETROGEOCHEMICAL AND ISOTOPE-GEOCHRONOLOGICAL SIGNATURES}

\subsection{Preuralides}

Island arc (735-720 Ma)-accretion (670 Ma) magmatism (island arc formations of the Enganepe uplift within the Central Uralian megazone), granite blocks in the melange zone and Yuznny massif (Suppl. 1; Suppl. 2; Fig. 1, b, c (2021)). The primitive island arc formations are represented by the most felsic melts of quartz diorites and tonalites, later granodiorites, tonalites, and plagiogranites, calc-alcaline (Fig. 2, a, b). These rocks belong to the normal petrochemical series in terms of the chemical composition, sometimes with somewhat higher alkalinity (sodium). The substratum is heterogeneous (Fig. 2, c), there is a displacement in the compositional points of the preuralides (island arc, collisional, riftogenic) and uralides (primitive island arc island arc) fields in the peraluminous field, which indicates a significant share of crustal (recycled) material in the formation of granitoids.

These rocks belong to the I-type granites and even to the M-type granites in some parameters [Pystin et al., 2011]. The composition points occupy fields of island-arc granitoids in the discriminant geodynamic diagrams (Fig. 2, g, h). The REE distribution patterns show a wide spread of LREE values, similar HREE values, and the minimum Eu anomaly (Fig. 3, I-a). As usual, spidergrams show the predominance of large-ion-lithophile elements over high-filed-strength elements (Fig. 3, II-a), distinct maximums of K, M-HREE, Y, and minimums of Ti, Sr, bidirectional $\mathrm{Nb}, \mathrm{Ta}$, and $\mathrm{Pb}$ anomalies. These features are associated with different island arc complexes in the Kharbey block and Enganepe uplift.

Collisional (650-520 Ma) magmatism marks the development of the Timan Orogen (Timanides-Preuralides) and its break-up. Most of the granitoid massifs of this stage are 
(a)

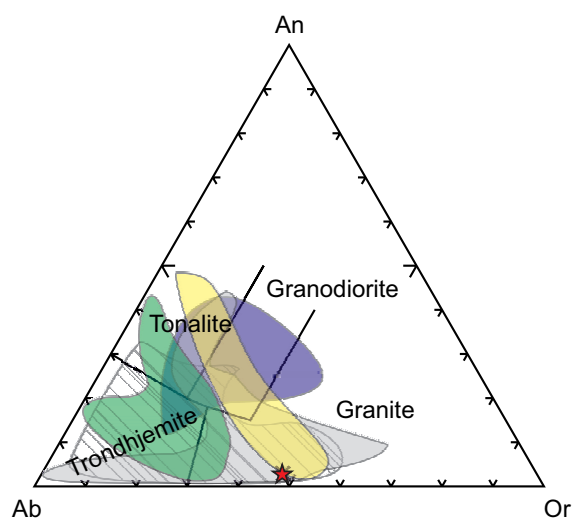

(c)

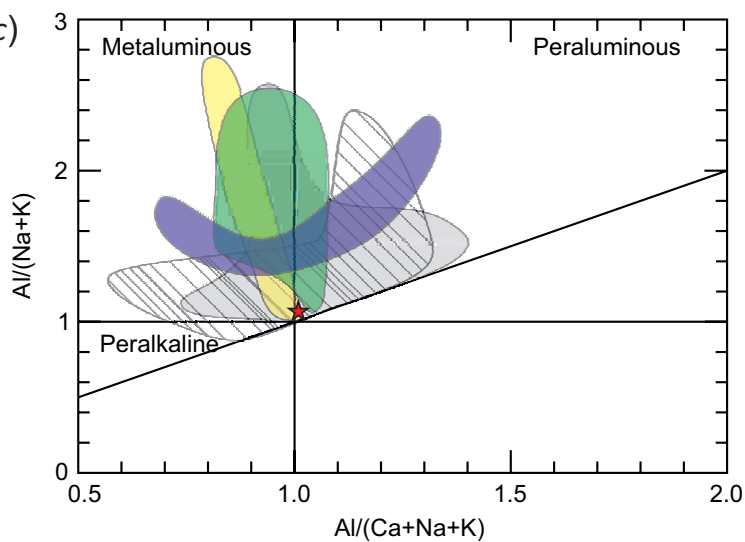

$(e)$

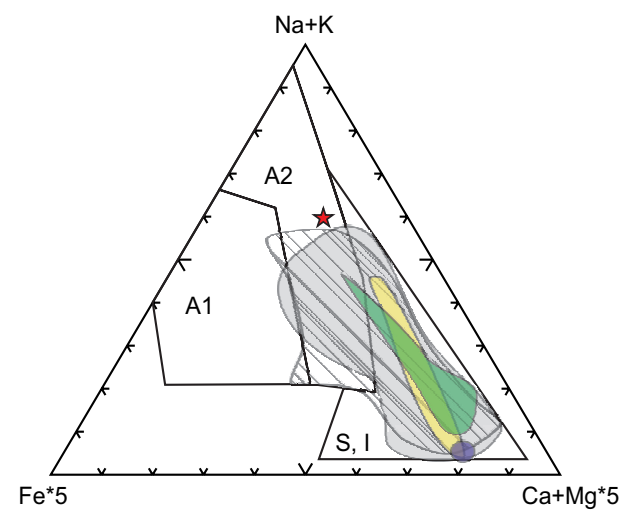

(g)

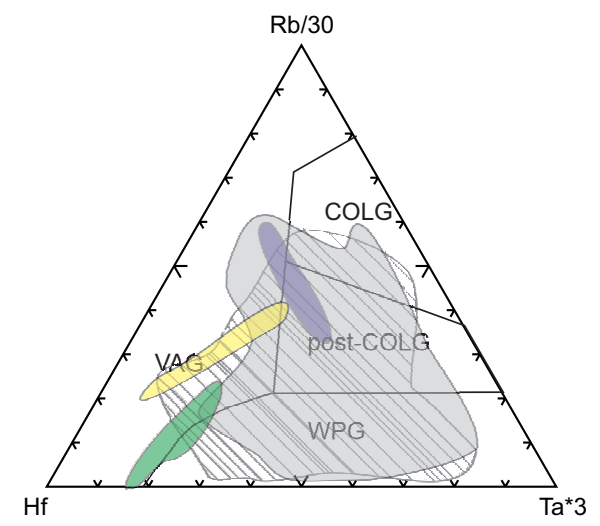

(b)

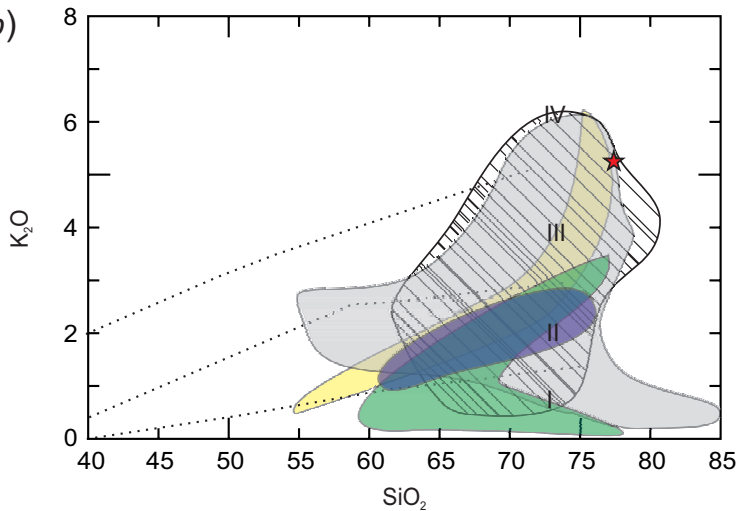

(d)

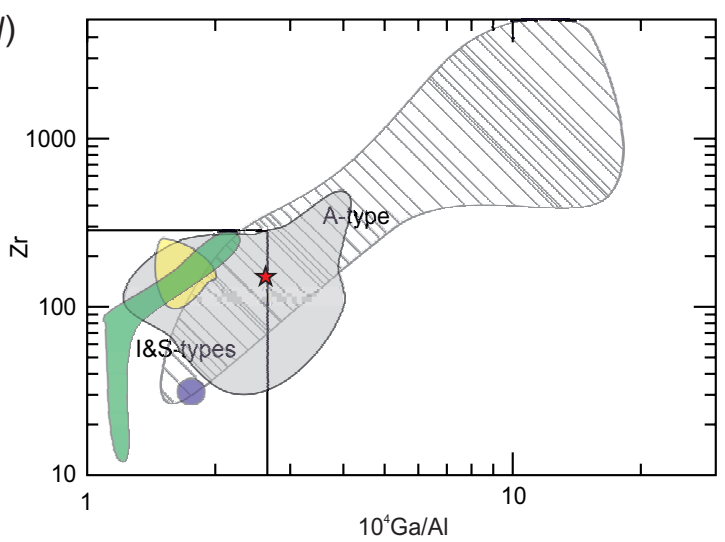

(f)

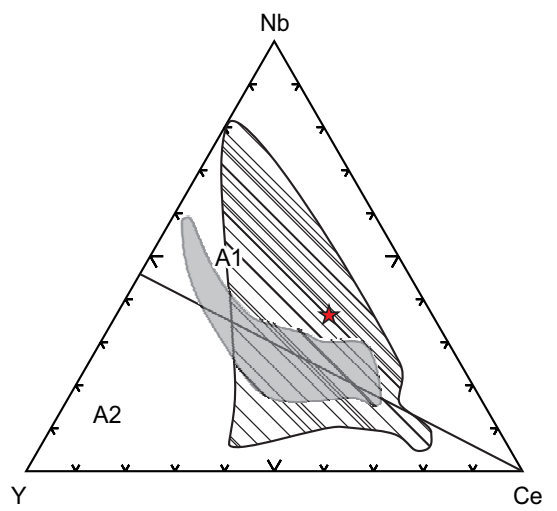

(h)

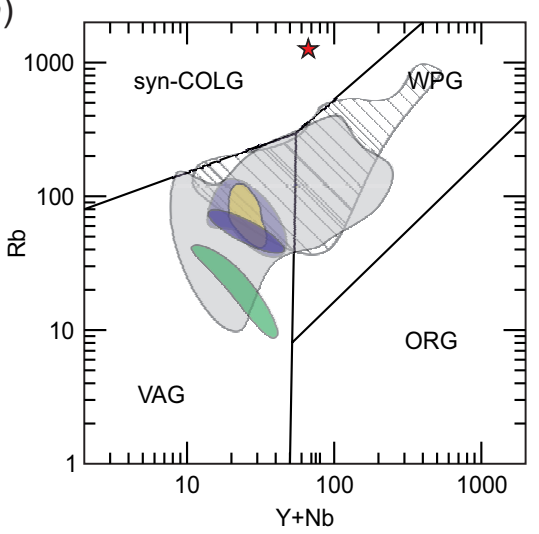

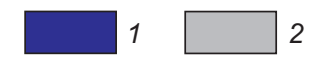

$2 \mathbb{M} 3$
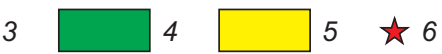

Fig. 2. Petro-geochemical discriminant diagrams of granitoids.

O'Connor diagram (a) [O'Connor, 1965], $\mathrm{SiO}_{2}-\mathrm{K}_{2} \mathrm{O}$ diagram (b) [Peccerilo, Taylor, 1976]; field: I - tholeiite series, II - calc-alkaline series, III - high-K calc-alkaline Series, IV - shoshonite series. Picolli diagram (c) [Maniar, Piccoli, 1989], Zr-104 Ga/Al diagram (d) [Whalen et al., 1987], diagram $\mathrm{Fe}_{2} \mathrm{O}_{3}{ }^{*} \times 5-\left(\mathrm{Na}_{2} \mathrm{O}+\mathrm{K}_{2} \mathrm{O}\right)-(\mathrm{CaO}+\mathrm{MgO}) \times 5(\mathrm{~g} / \mathrm{mol})(e)$ [Grebennikov, 2014], Nb-Y-Ce diagram (ppm) for A-type granites $(f)$ 
[Eby, 1992], Harris geodynamic diagram (g) [Harris et al., 1986]; field: COLG - Collision Granites, post-COLG-post-Collision Granites WPG - Within Plate Granites, Pearce geodynamic diagram [Pearce et al., 1984]; field: COLG - Collision Granites, WPG - Within Plate Granites, VAG - Volcanic Arc Granites, ORG - Ocean Ridge Granites (h).

Complexes of Preuralides: 1 - island-arc, accretionary (735-720, $670 \mathrm{Ma}), 2$ - collisional (650-520 Ma), 3 - rift-related (520-480 Ma); Complexes of Uralides: 4 - primitive island arc 460-430 Ma, 5 - mature island arc 412-368 Ma, 6 - early collisional (360-316 Ma).

Рис. 2. Петро-геохимические диаграммы для гранитоидов.

Диграмма О`Коннера (a) [O’Connor, 1965], диаграмма $\mathrm{SiO}_{2}-\mathrm{K}_{2} \mathrm{O}$ (b) [Peccerilo, Taylor, 1976]; поля: I - толеитовая серия, II - известково-щелочная серия, III - высококалиевая известково-щелочная серия, IV - шошонитая серия. Диаграмма Пиколли (c) [Maniar, Piccoli, 1989], диаграмма $\mathrm{Zr}-10^{4} \mathrm{Ga} / \mathrm{Al}(d)$ [Whalen et al., 1987], диаграмма $\mathrm{Fe}_{2} \mathrm{O}_{3}{ }^{*} \times 5-\left(\mathrm{Na}_{2} \mathrm{O}+\mathrm{K}_{2} \mathrm{O}\right)-(\mathrm{CaO}+\mathrm{MgO}) \times 5$ (мол. кол.) (e) [Grebennikov, 2014], диаграмма Nb-Y-Се (г/т) для гранитов А-типа (f) [Eby, 1992], геодинамическая диаграмма Харриса $(g)$ [Harris et al., 1986]; поля: COLG - коллизионные граниты, post-COLG - постколлизионные граниты, WPG - внутриплитные граниты, геодинамическая диаграмма Пирса [Pearce et al., 1984]; поля: COLG - коллизионные граниты, WPG - внутриплитные граниты, VAG - граниты вулканических дуг, ORG - граниты океанических хребтов $(h)$.

Комплексы: (доуралиды) 1 - островодужные, аккреционные (735-720, 670 млн лет), 2 - коллизионные (650-520 млн лет), 3 рифтогенные (520-480 млн лет); (уралиды) 4- островодужные (примитивная островная дуга 460-430 млн лет), 5 - островодужные (зрелая островная дуга 412-368 млн лет), 6 - коллизионные ранние (360-316 млн лет).

exposed within the Central Uralian megazone. Differentsized granite bodies, exposed among high-grade metamorphic rocks of the Kharbey and Nyarta blocks and their frames throughout the north of the Urals, are also included (Suppl. 1; Suppl. 2; see Fig. 1, b, c (1-19, 22-23, 37-79)).

The previous analysis by A.A. Soboleva [Soboleva et al., 2005a; Soboleva, Udoratina, 2010] has shown that I-, A-, S-type granitoids with varying petrogeochemical characteristics were emplaced simultaneously in this time.

Analysis of new U-Pb zircon ages of granitoids (Suppl. 1; see Fig. 1) obtained in recent years confirms this (Fig. 4, a, $b, c)$. The maximum number of dates were obtained for granitoids emplaced during the period of 650-520 Ma; they are characterized by different petrogeochemical signatures.

M-type granites. Subpolar Urals: Panechaiz complex, Perevalny massif and a small body on the eastern slope of Mount Severnoe Lezvie (Suppl. 1; Suppl. 2; see Fig. 1, b, c (43, 43-1).

I-type granites. Polar Urals: West Borzovsky site, Poetarsky, Gerdiz (573, 529 Ma), Evyugan complex, Kharbey complex (664, 571, 561, 557 Ma), Sandibey and Malyi Sandibey massifs (Suppl. 1; Suppl. 2; see Fig. 1, b, c (1, 5-6, 9, 17-19); Subpolar Urals: Lapchavozh, Naroda (548, 544 Ma), Svobodnensky, Malaya Tynagota, Vangyr (Suppl. 1; Suppl. 2; see Fig. 1, b, c (37, 42, 49-52); Northern Urals: Torreporeiz, Yadzhydlyagsky, Verkhnyaya Man`ya, small bodies of the Isherim block, Moiva, Posmak, Vels, and Vagran (Suppl. 1; Suppl. 2; see Fig. 1, b, c (67-68, 70, 72, 76-79)).

A-type granites. Polar Urals: Neudachny, Ust-Mramorny (536 Ma), Longotyugan (605 Ma), Taikeu (564 Ma), Syadatayakha (544 Ma), Kharbey (592 Ma), Malyi Sandibey (Suppl. 1; Suppl. 2; see Fig. 1, b, c (10-12, 14-16, 19); Subpolar Urals: Kozhim, Pioner-gora, Torgovaya, Keftalyk, Khartess, Kulemshor (544-540 Ma) (Suppl. 1; Suppl. 2; see Fig. 1, b, c $\left(40\left(A_{2}\right), 54,58-60,63\left(A_{2}\right)\right)$;

S-type granites. Subporar Urals: Nyarta complex, Nikolayshor, Ambarshor, Khalmeryu, Lavkashor, Mansaraiz (Suppl. 1; Suppl. 2; see Fig. 1, b, c (44-48, 53).

The petrographic and petrochemical series of these rocks are wide, varying from quartz diorites to leucogranites (see Fig. 2, a). It is difficult to summarize the characteristics of a large number of heterogenous massifs. In general, the field of composition points of this age stage shows a wide variation in contents of $\mathrm{SiO}_{2}$ and alkalis; rocks belong to normal and alkaline petrochemical series (see Fig. 2, b). The material of different origin was involved in the melting substrate (see Fig. 2, c); composition points lie in the fields of I-, A-, S-granites (see Fig. 2, d, e). Composition points of A-type granites lie near the line between A1- and A2-type granitoids (see Fig. 2, f). In the discriminant geodynamic diagrams, one can see a general swarm of composition points at the intersection of the boundaries of island arc, collision, and intraplate fields (see Fig. 2, g, h).

I-type granites. The chondrite-normalized REE distribution patterns (see Fig. 3, I-b) are characterized by a wide field with equal shoulders (the same contents of LREE and HREE) with bidirectional Eu minimum. Spidergrams show a general predominance of large-ion-lithophile elements over high-filed-strength elements (see Fig. 3, II-b). These granites are characterized by minimum $\mathrm{Ti}, \mathrm{P}, \mathrm{Eu}$, and $\mathrm{Zr}$ values, maximum $\mathrm{K}, \mathrm{Pb}, \mathrm{Tb}, \mathrm{Cs}$, and M-HREE values, and bidirectional $\mathrm{Sr}, \mathrm{Nb}, \mathrm{Cs}$, and Ce anomalies.

A-type granites. The A-type granites in the chondritenormalized REE distribution patterns are characterized by wide LREE and HREE variations with a distinct bidirectional Eu anomaly (see Fig. 3, I-b). As seen in spidergrams, a predominance of of large-ion-lithophile elements over high-filed-strength elements (see Fig. 3, II-b). These granites are characterized by minimum $\mathrm{Nb}, \mathrm{Sr}$, $\mathrm{P}$, and Ti values, maximum $\mathrm{Pb}, \mathrm{Ta}, \mathrm{U}$, and MREE values, and bidirectional behavior of $\mathrm{K}, \mathrm{Zr}$, and $\mathrm{Cs}$.

S-type granites. The chondrite-normalized REE distribution patterns are characterized by similar LREE and HREE values with a distinct deep Eu minimum (see Fig. 3, I-b). The multispectra demonstrate the predominance of large-ionlithophile elements over high-filed-strength elements (see Fig. 3, II-b). The S-type granites are characterized by Eu, Ti, Ta, and $P$ minimal values, insignificant maximums in K, MREE, and $\mathrm{Y}$, and bidirectional behavior of Cs and LREE.

Scarce $\mathrm{U}-\mathrm{Pb}$ dates of detrital zircon cores provide new information on the granite-producing substratum: S-type granites (Lavkashor (1756 Ma)), I-type granites (Gerdiz 
(a)

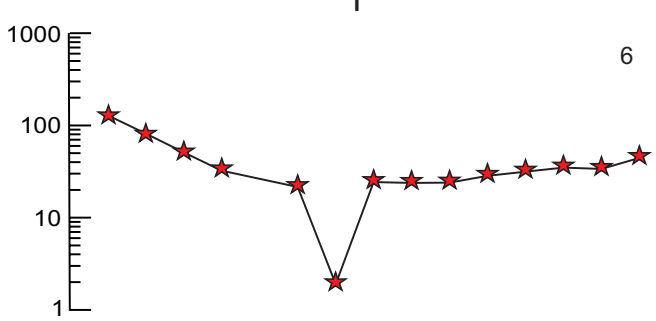

(b)

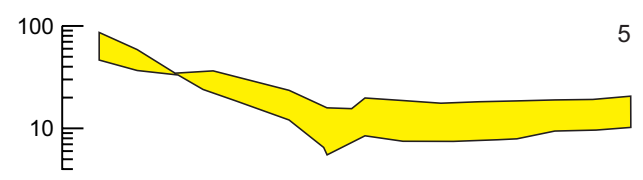

(c)

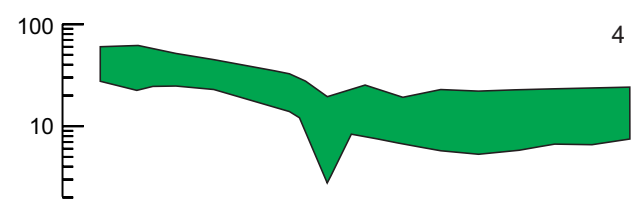

(d)

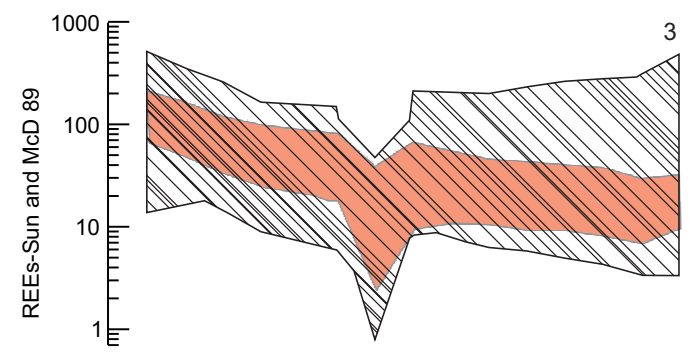

$(e)$

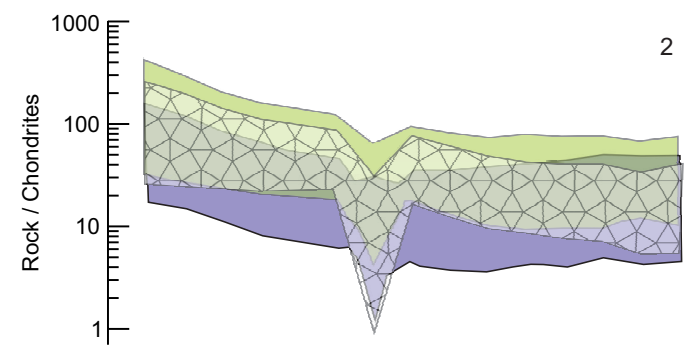

$(f)$

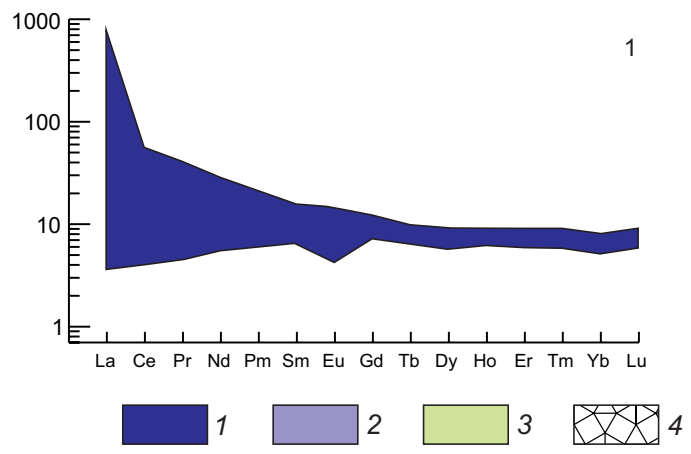

II
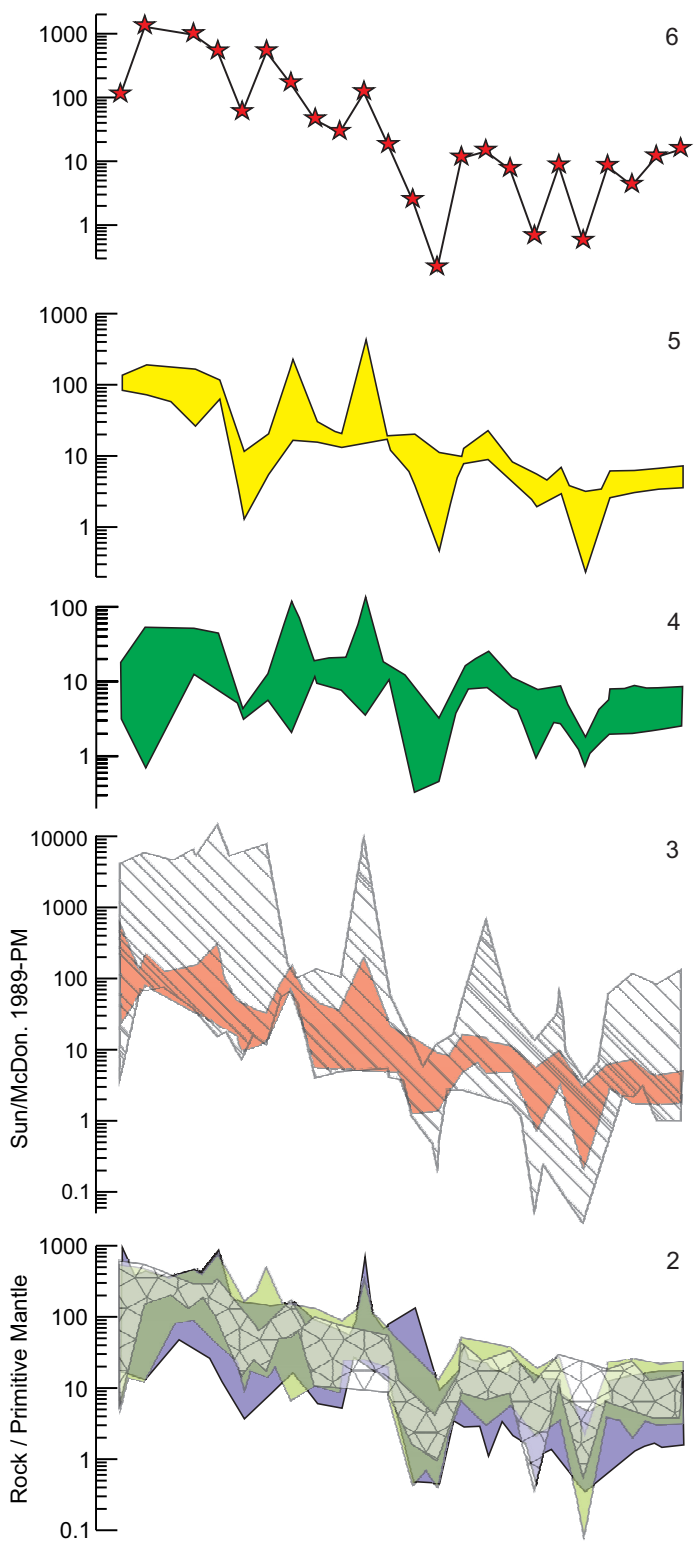

1

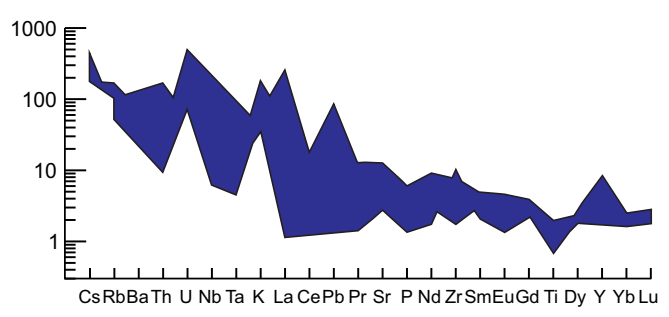

Fig. 3. The chondrite-normalized REE distribution patterns (I), spidergrams (II).

Complexes of Preuralides: 1 - island-arc, accretionary (735-720, $670 \mathrm{Ma}$ ), collisional (650-520 Ma): 2 - I-type, 3 - A-type, 4 - S-type), rift-related (520-480 Ma): 5 - I-type, 6 - A-type. Complexes of Uralides: 7 - primitive island arc (460-430 Ma), 8 - mature island-arc (412-368 Ma), 9 - pre-collision (360-316 Ma).

Рис 3. Диаграмма распределения РЗЭ (I), спайдер-диаграмма (II).

Комплексы: (доуралиды) 1 - островодужные, аккреционные (735-720, 670 млн лет); коллизионные (650-520 млн лет): 2 I-тип, 3 - А-тип, 1 - S-тип), рифтогенные (520-480 млн лет): 5 - I-тип, 6 - А-тип; (уралиды) 7 - островодужные (примитивная островная дуга 460-430 млн лет), 8 - островодужные (зрелая островная дуга 412-368 млн лет), 9 - коллизионные ранние (360-316 млн лет). 
(a)

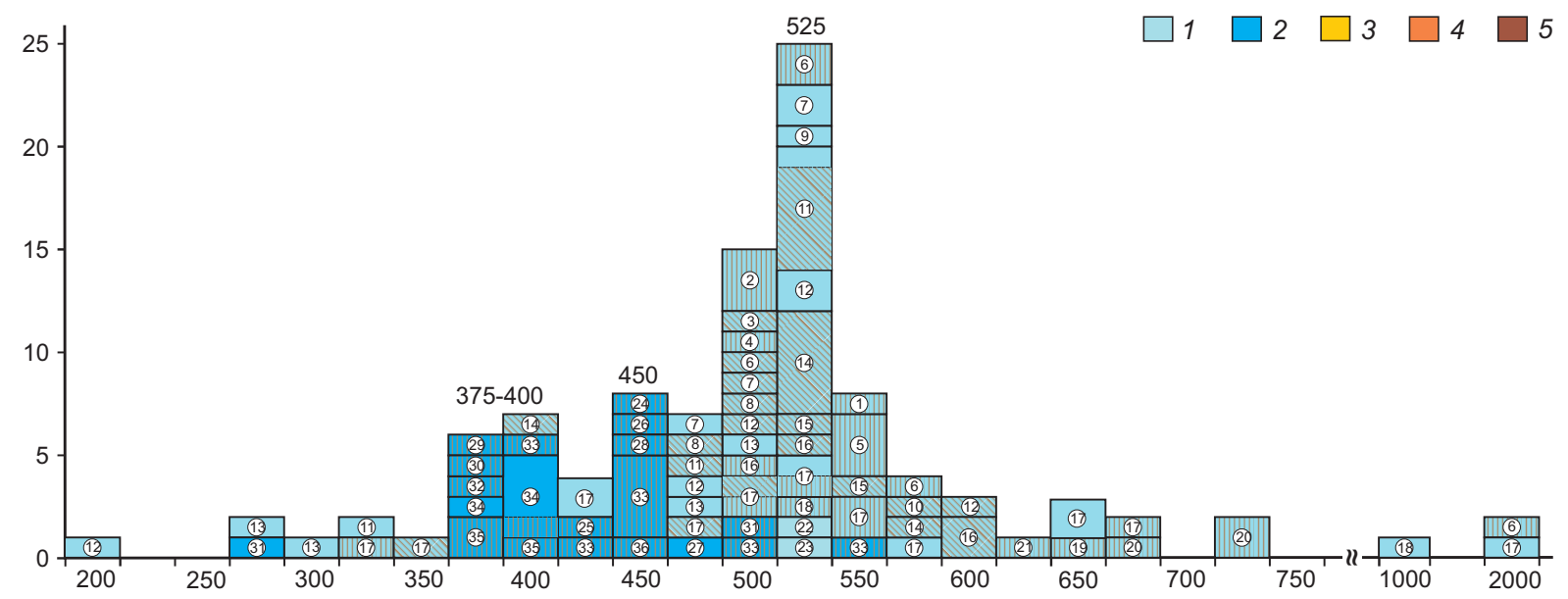

(b)

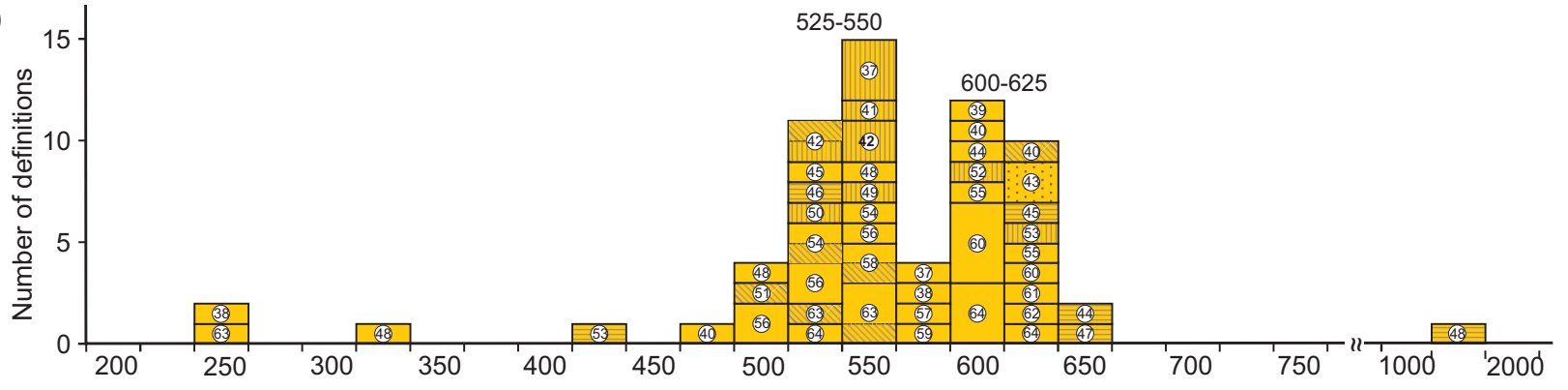

(c)
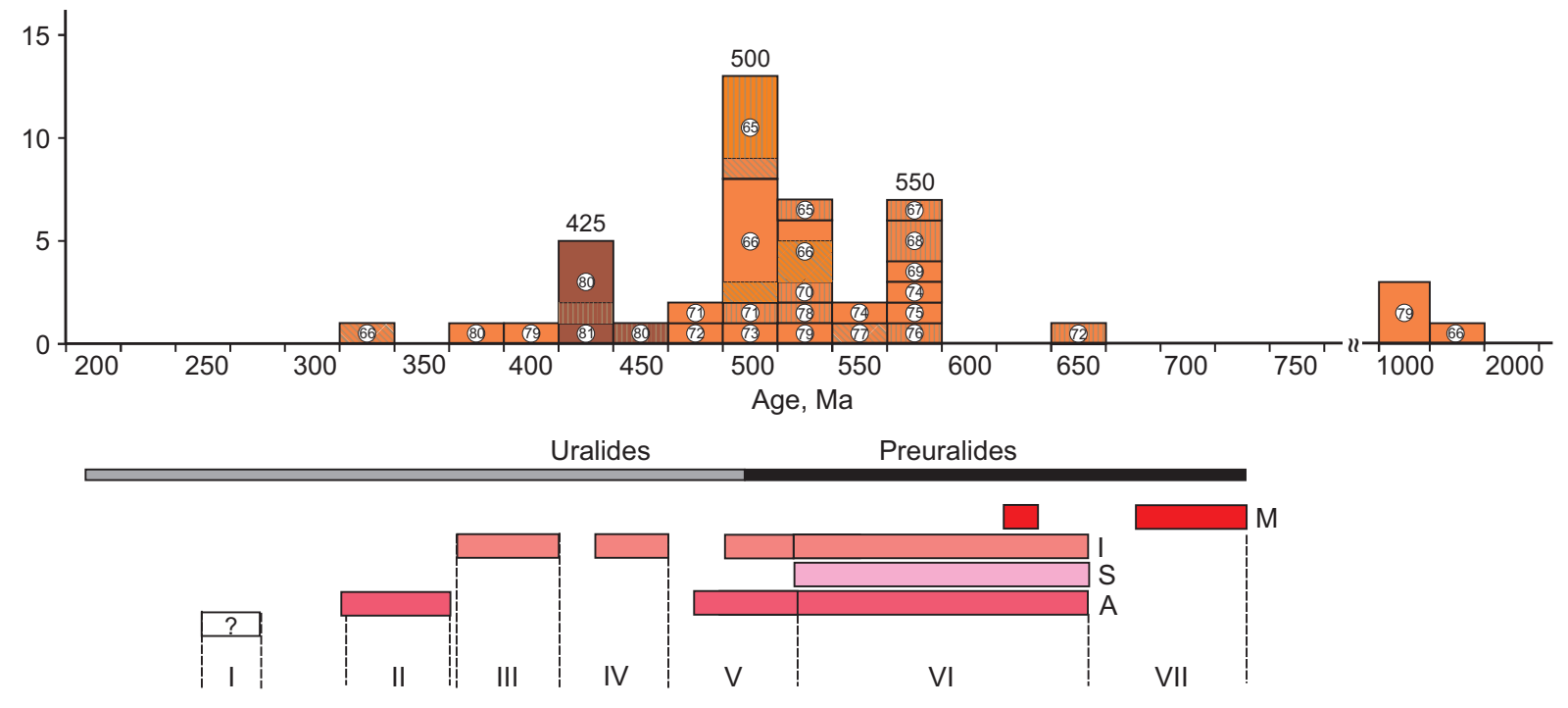

Fig. 4. The U-Pb age distribution histogram for zircons from granitoids of the north of the Urals (Polar Urals (a), Subpolar Urals $(b)$, Northern Urals (c)), according to [Soboleva et al., 2005a; Soboleva, Udoratina, 2010] with data amendments (Suppl. 1; Fig. 1, c).

The averaging step is $25 \mathrm{Ma}$. The duration of formation of different types of granitoids and the relationship with geodynamic regimes (d). Legend: 1 - Polar Urals (Central Uralian megazone); 2 - Polar Urals (East Uralian megazone); 3 - Subpolar Urals (Central Uralian megazone); 4 - Northern Urals (Central Uralian megazone); 5 - Northern Urals (East Uralian megazone). Numbers in circles correspond to the numbers in Suppl. 1; Fig. 1, c. Hatching (types of granites): points (M), vertical (I), oblique (A), and horizontal (S). Uralides: I - late collisional, II - early collisional, III - mature island arc, IV - primitive island arc; Preuralides: V - rift-related, VI - collision, VII - island arc.

Рис 4. Гистограмма U-Pb возрастов цирконов из гранитоидов севера Урала (Полярный Урал $(a)$, Приполярный Урал $(b)$, Северный Урал (c)) по [Soboleva et al., 2005a; Soboleva, Udoratina, 2010] с дополнениями данных (Прил. 1; рис. 1, с).

Шаг осреднения 25 млн лет. Длительность формирования гранитоидов различных типов и соотношение с геодинамическими режимами формирования $(d)$. Условные обозначения: 1 - Полярный Урал (Центрально-Уральская мегазона); 2 - Полярный Урал (Восточно-Уральская мегазона); 3 - Приполярный Урал (Центрально-Уральская мегазона); 4 - Северный Урал (Центрально-Уральская мегазона); 5 - Северный Урал (Восточно-Уральская мегазона). Цифры в кружках соответствуют цифрам в Прил. 1 и на рис. 1, b, с. Штриховка (типы гранитов): точки (M), вертикальная (I), косая (A), горизонтальная (S). Уралиды: I - позднеколлизионные, II - раннеколлизионные, III - островодужные зрелой островной дуги, IV - островодужные примитивной островной дуги; доуралиды: V - рифтогенные, VI - коллизионные, VII - островодужные. 
(1788 Ma), small bodies of the Kharbey block (1896 Ma), Sandibey (1217 Ma), and Vagran (1034, 1192, $1221 \mathrm{Ma})$ ), and A-type granites (Mankhambo (1390)). Granite melt was derived from the protolith, which could include products of destruction and redeposition of rocks of the ancient crystalline basement and later Riphean formations.

Rift-related (520-480 Ma) magmatism. Granitoid massifs belonging to this stage are exposed in the Central Uralian megazone. A-type granitoids prevail. However, I-type granite massifs, formed at the pre-rifting and rifting stages continued to emplace.

I-type granites. Polar Urals: Kyzygey complex, Left Shchuchye, Kharbey complex (Suppl. 1; Suppl. 2; see Fig. 1, b, c (2, 4-6, 9, 17); Subpolar Urals: Naroda (Suppl. 1; Suppl. 2; see Fig. 1, b, c (42); Northern Urals: Ilyaiz, Sedlovataya Parma, small bodies of the Isherim block (Suppl. 1; Suppl. 2; see Fig. 1, b, c (65, 71-72);

A-type granites. Polar Urals: Ochety, Gerdiz (496), small body in the Marunkeu, Ingilor, Ust-Mramorny, Longotyugan, Longot, Taikeu, Syadatayakha, Kharbey (Suppl. 1; Suppl. 2; see Fig. 1, b, c (3, 6-8, 11-16); Subpolar Urals: Naroda, Tynagota, Kulemshor (Suppl. 1; Suppl. 2; see Fig. 1, b, c (42, 51, 63); Northern Urals: Mankhambo (Suppl. 1; Suppl. 2; see Fig. 1, b, c (66).

In terms of petrography and petrochemistry, these granites vary from plagiogranites to leucogranites (see Fig. 2, a). Composition points of rocks of this age stage vary in narrower limits; these rocks belong to rocks of normal and alkaline petrochemical series (see Fig. 2, b). The melting substratum involves both crustal and mantle material (see Fig. 2, c), composition points occupy fields of I- and A-type granites (see Fig. 2, d, e). Composition points of A-type granites occupy a wide area, shifting towards the field of more mantle A1-type granites - granites with minimal participation of crustal material in melting (see Fig. 2, f). A swamp of composition points is shifted towards the field of intraplate formations in the discriminant geodynamic diagrams (see Fig. 2, g, h).

I-type granites. The chondrite-normalized REE distribution patterns (see Fig. 3, I-c) show little REE composition variations with a distinct Eu minimum. Spidergrams show the predominance of large-ion-lithophile elements over high-filed-strength elements (see Fig. 3, II-c). These granites are characterized by small minimums of Ti, P, Eu, Sr, Nb, $\mathrm{La}$, slight maximums of $\mathrm{K}, \mathrm{Pb}, \mathrm{U}, \mathrm{M}-\mathrm{HREE}$, and bidirectional Cs anomalies.

A-type granites. The chondrite-normalized REE distribution patterns (see Fig. 3, I-c) show a very wide field of LREE and HREE variations, sometimes with predominance of HREE (typical of metasomatically altered rock varieties of the Taikeu site, Polar Urals), with a strongly pronounced deep Eu minimum. spidergrams show a general predominance of large-ion-lithophile elements over high-filed-strength elements (see Fig. 3, II-c), but with the widest variations in contents of elements. These granites are characterized by minimums of $\mathrm{La}, \mathrm{P}, \mathrm{Eu}, \mathrm{Ti}$, maximums of $\mathrm{Th}, \mathrm{U}, \mathrm{Ta}, \mathrm{Pb}$, HREE, bidirectional behavior of Cs, and an absence of variations in $\mathrm{K}$ and $\mathrm{Sr}$.
As seen in Fig. 4, the maximum of formation of rocks with these petrogeochemical characteristics is estimated at $500 \mathrm{Ma}$.

\subsection{Uralides}

Primitive island arc granites (460-430 Ma) of the East Uralian megazone. As seen in Fig. 4, the I-type granitoids were emplaced in this period.

I-type granitoids. Polar Urals: Yanganape, Nganotsky I, Yalyape, Rechnoy Paleovolcano, Lagortayu complex, Pogurey (Suppl. 1; Suppl. 2; see Fig. 1, b, c (24-28, 33); Northern Urals: Petropavlovsk complex, Severorudnichny complex (Suppl. 1; Suppl. 2; see Fig. 1, b, c (80-81).

As a rule, these granitoids are in a narrow range of petrographic compositions: from quartz diorites to tonalites and rarely granites (see Fig. 2, a). Petrochemically, these rocks belong to normal, low-K, Na series (see Fig. 2, b). As a rule, these rocks are derived from a mantle source (see Fig. 2, c). The composition points occupy the I-type granite field (see Fig. 2, d, e). Composition points of these granitoids lie in the field of island arc formations on discriminant geodynamic diagrams (see Fig. 2, g, h).

The chondrite-normalized REE distribution patterns (see Fig. 3, I-d) demonstrate low REE contents and narrow variations of REE contents with bidirectional Eu minimum. The spidergrams show a slight enrichment in large-ionlithophile elements relative to high-filed-strength elements (see Fig. 3, II-d). These rocks are characterized by minimum $\mathrm{Ti}, \mathrm{P}, \mathrm{Eu}, \mathrm{Sr}$, and $\mathrm{Nb}$ values, insignificant $\mathrm{K}$ maximums, and bidirectional $\mathrm{Cs}, \mathrm{Rb}, \mathrm{Ta}, \mathrm{K}, \mathrm{Pb}$, and $\mathrm{Zr}$ anomalies.

Mature island arc granitoids (412-368 Ma) of the East Uralian megazone. I-type granitoids: Yurmenek, Canyonny, Sob, and Yanaslor massifs (Suppl. 1; Suppl. 2; see Fig. 1, b, c (29-30, 32, 34-35).

In terms of mineral composition, rocks are represented by quartz diorites, granodiorites, and granites (see Fig. 2, a). Petrochemically, these rocks belong to normal, low-K, Na series; normal $\mathrm{K}$ formations are less common (see Fig. 2, b). The sedimentary (crustal) material (see Fig. 2, c) makes the minimal contribution to the granite melt; composition points of granites lie in the field of I-type granites (see Fig. 2, d, e). In the geodynamic diagrams, composition points of rocks lie in the field of island arc granitoids (see Fig. 2, g, h).

Rocks are characterized by low REE content. The chondrite-normalized REE distribution pattern (see Fig. 3, I-d) shows a non-differentiated type of spectrum close to the basalt one with a practical absence or an indistinct Eu minimum. Multispectra show a predominance of large-ion-lithophile elements over high-filed-strength elements and are characterized by pronounced minimums of $\mathrm{Nb}, \mathrm{P}, \mathrm{Ti}$, the same distinct maximums of $\mathrm{K}, \mathrm{Pb}$, and lower contents of $\mathrm{Zr}$ and Gd (see Fig. 3, II-d).

The onset of the collision in the north of the Urals is dated to the Carboniferous, while its termination - to the Late Permian [Puchkov, 2010]. Granitoid massifs emplaced in this period are still unknown, but some dates of zircons from granitoids marked these stages. Based on the latter, we have distinguished two stages: 
Early collisional stage (360-316 Ma). In the Polar Urals, this stage is recorded in rims of zircons from the Yanganape and Canyonny massifs of the East Uralian megazone of the Shchuchiya synform and those from granite bodies of the Kharbey block of the Central Uralian megazone and granites of the Ust-Mramorny site.

In the Northern Urals and Central Uralian megazone, the rare-metal phase of granites of the Mankhambo massif include zircons with early collisional ages (336 Ma). Petrochemically, they are high-K granites (see Fig. 2, a, b), belonging to the A-type (see Fig. 2, d, f). Composition points of these granites lie in the field of collisional granites on the discrimination geodynamic diagrams (see Fig. 2, g, h). They are characterized by weakly differentiated REE distribution patterns with a distinct Eu minimum (see Fig. 3, I-a). The primitive mantle-normalized distribution spectra show the predominance of large-ion-lithophile elements, such as Cs, $\mathrm{Rb}, \mathrm{Ba}$, and $\mathrm{U}$ over high-filed-strength elements, such as $\mathrm{Zr}$ and Y (see Fig. 3, II-a).

Late collisional stage (277-249 Ma). The age values of this interval were obtained for some zircons from granites of the Khatalambo-Lapchinsky and Kulemshor massifs of the Central Uralian megazone (Subpolar Urals) and some zircons from granodiorites of the East Uralian megazone (Northern Trans-Urals, Polar Urals). Thus, petrogeochemical signatures of the studied series of granitoids (dated samples) mark different geodynamic regimes of formation in the north of the Urals (Fig. 4, d).

The presence of granitoid massifs of two collisional stages in the north of the Urals is confirmed by dates of detrital zircons from the Paleozoic formations of the West Uralian megazone of the Polar Urals. Thus, the zircon assemblage of the early collisional stage was recognized in the Upper Carboniferous Kechpel Formation, while that of the late collisional stage - in the Lower Permian Gusikhinskaya Formation [Kuznetsov et al.,2013].

\section{ISOTOPE-GEOCHEMICAL SIGNATURES}

We have obtained $\mathrm{O}, \mathrm{Hf}$, and $\mathrm{Nd}$ isotope compositions for the nearly third part of all massifs, which also have the $\mathrm{U}-\mathrm{Pb}$ ages (Suppl. 1; Fig. 5, a, b, c).

\subsection{Oxygen isotope composition.}

Based on the genetic classification, granitoids, close in composition to I-, S-, A-types and, to a lesser extent, M-type, are distinguished among complexes of the Preuralides. According to the classification [Chappell, White, 1974; Whalen et al., 1987], the I-type granitoids are typical of the Uralide complexes.

Polar Urals. Preuralides. The $\delta^{18} \mathrm{O}_{\mathrm{zrn}}$ value (\%o) for island arc I-type granitoids (a block in the Manyukuyakha serpentinite melange, Enganepe uplift) is +5.58 (Suppl. 1; Fig. 5, a). The $\delta^{18} \mathrm{O}_{\mathrm{zrn}}$ value for collisional A-type granites is +5.71 (Longotyugan (605 Ma)), while in rift-related granites, it varies from +4.7 to +7 . The lowest $\delta^{18} \mathrm{O}_{\mathrm{zrn}}$ value $(+4.7)$ (close to mantle ones) is characteristic of zircons from granitoids of the Ingilor massif. Other massifs are characterized by crustal-mantle $\delta^{18} \mathrm{O}_{\mathrm{zrn}}$ values: alkaline massifs of the Syadatayakha massif $(+6.1)$, granites of the Marunkeu block (+6.22), granitoids of the Gerdiz massif $(+6.9)$. The metasomatically altered granites of the Taukeu site have moderate $\delta^{18} \mathrm{O}_{\mathrm{zrn}}$ values varying from +5.7 to +6.3 .

Polar Urals. Uralides. Based on studying the 0 isotope composition in zircons from the Devonian island arc granitoids of the East Uralian megazone (Polar Urals), the following $\delta^{18} \mathrm{O}$ values were obtained: quartz diorites of the Sobsky massif $(+5.7 \% 0)$, granites of the Yanaslor massif $(+4.2 \% 0)$. Such $\delta^{18} 0$ values are common in rocks, derived from a non-contaminated mantle source.

Subpolar and Northern Urals. Preuralides. Regardless of the granite composition, $\delta^{18} 0$ value in zircons varies from +7.10 to $+8.51 \%$ o (low values are rarely noted), indicating the crystallization of zircons from crustal melt and a possible presence of subducted sediments and seawater in the substrate [Valley et al., 1998]. The lowest values (+7.10\%0) in this group of granitoids are characteristic of zircons from quartz diorites of the Perevalny massif (625 $\pm 8 \mathrm{Ma})$, which are intermediate in composition between I- and M-type granites (Suppl. 1; see Fig. 1, b, c, 43-1).

The I-type granitoids are characterized by wide variations in mineral composition from quartz diorites to leucogranites. The $\delta^{18} \mathrm{O}$ in zircons varies from +7.16 to $+8.51 \%$ (Suppl. 1). The A-type granites (Khatalamba-Lapchinsky massif) are also characterized by high $\delta^{18} 0$ values (+7.47\%0) in zircons. The $\delta^{18} \mathrm{O}$ value in gneissic granites of the Nyarta complex, referred to as S-granites, is $+7.31 \%$ (up to $+7.47 \%$ in the S-type leucogranites of the Yaptoyakha massif [Soboleva et al., 2015]).

Granitoids of the final post-orogenic evolution stage of the Preuralides and practically synchronously emplaced granitoids of the pre-rifting and early rifting stages of the Uralides are combined into the group of younger granitoids since there are no clear criteria to discriminate them. Granites and leucogranites, belonging to the I- and mainly A-type varieties, dominate in this group. The granitoids of this group are characterized by lower $\delta^{18} 0$ values in zircons, up to very low ones. Thus, $\delta^{18} \mathrm{O}$ in zircons from I-type granitoids varies from +6.22 to $+7.33 \%$, reaching the maximum in leucogranites of the Ilyaiz massif. Zircons from A-type granites are characterized by even lower $\delta^{18} 0$ values from +3.27 to $+6.86 \%$. Abnormally low $\delta^{18} \mathrm{O}$ values were measured in zircons from granites of the Mankhambo massif ( $+4.7 \%$ ), Kulemshor massif $(+3.27 \% 0)$, and the Lemvinsky massif (out of consideration here) $(+3.47-+3.79 \%$ ) [Soboleva et al., 2015]. These values are significantly lower than typical mantle values $(+5.3 \pm 0.6 \%$ [Valley et al., 1998].

\subsection{Nd isotope composition}

$\mathrm{Nd}$ isotope composition was obtained for whole-rock compositions of 11 massifs. All these massifs are characterized by different negative and positive values (Suppl. 1; Fig. 5, b).

The Polar Urals. Preuralides. Island arc granitoids (a plagiogranite vein crossing a quartz diorite block in the Manyukyuyakha serpentinite mélange, $670 \mathrm{Ma}$ ) yielded a crustal-mantle $\varepsilon N d$ value of +1.7 [Khain et al., 2003]. 
(a)

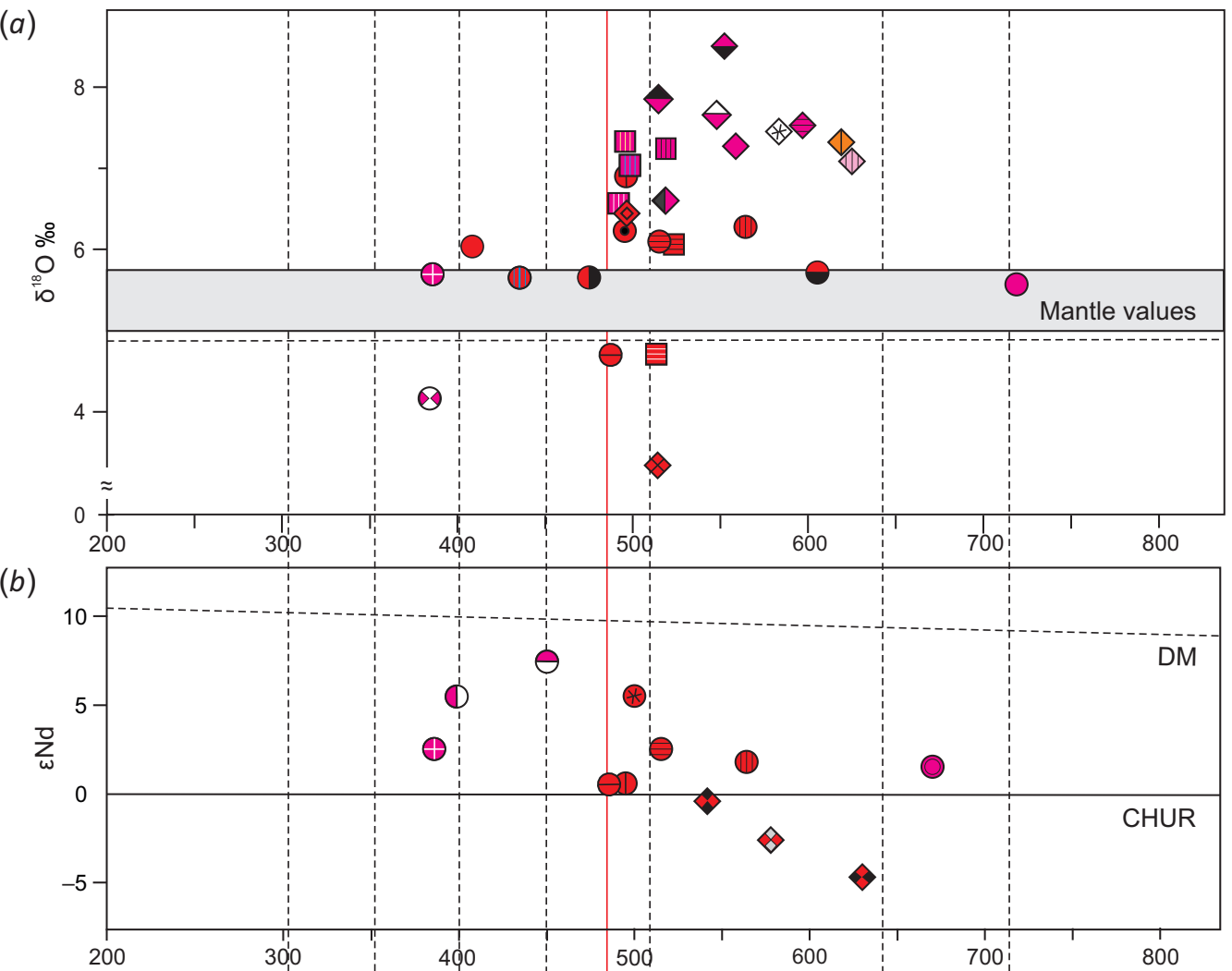

(c)

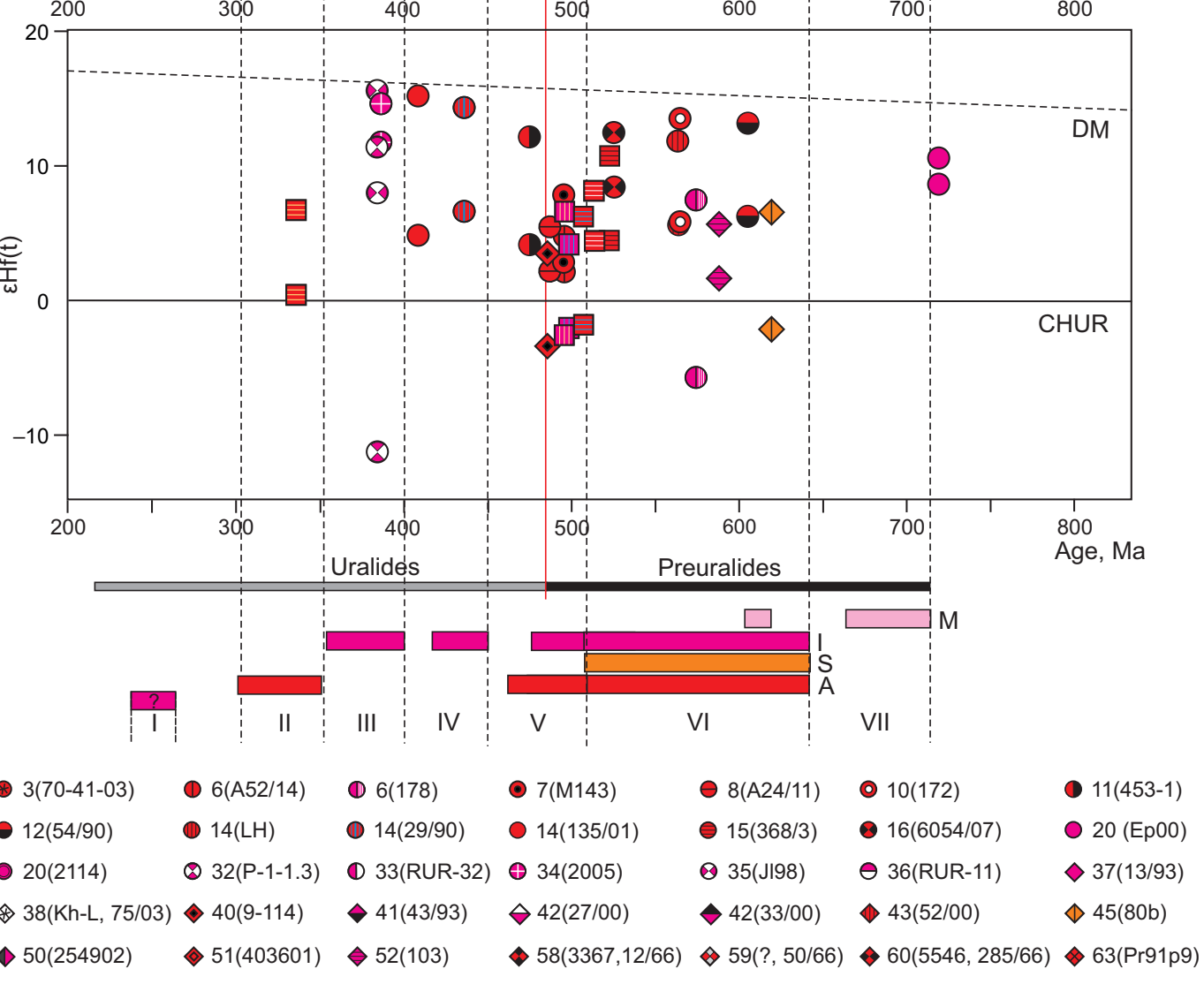

Fig. 5. The $\mathrm{O}_{\mathrm{zrn}}(a), \mathrm{Nd}_{\mathrm{wr}}(b), \mathrm{Hf}_{\mathrm{zrn}}(c)$ isotope compositions.

CHUR - chondrite reservoir, DM - depleted mantle. Legend: numbers correspond to the numbers of massifs in Suppl. 1 and Fig. 1, b, c. I-VII - see on the Fig. 4.

Рис. 5. Изотопный состав $\mathrm{O}_{\mathrm{zrn}}(a), \mathrm{Nd}_{\mathrm{wr}}(b), \mathrm{Hf}_{\mathrm{zrn}}(c)$.

CHUR - хондрит, DM - деплетированнная мантия. Условные обозначения: номера соответствуют номерам массивов в Прил. 1 и на рис. 1, b, c. I-VII - см. на рис. 4. 
The A-type granites of the Taikeu massif (564 Ma, sample LH, Suppl. 1; see Fig. 1, b, c (14)), marking the collisional stage, yielded the only $\varepsilon N d$ value $(+1.8)$, which is referred to crustal-mantle ones [Valley et al., 1998].

Subpolar Urals. The Hf isotope composition was obtained for the A-type collisional granitoids (Torgovaya, Keftalyk, and Khartes massifs, Suppl. 1; see Fig. 1, b, c (58-60). The $\varepsilon$ Hf values are crustal: $0.3,-2.7,-4.8$, respectively [Udoratina et al., 2012a, 2014a]. Composition points ( -2.7 and -4.8$)$ of granitoids of these massifs lie in the field $A 2$ of more crustal rocks (A1- $\mathrm{A}_{2}$ diagram; see Fig. 2, f), while the values of -0.3 lie at the boundary between $\mathrm{A} 1$ and $\mathrm{A}_{2}$ fields.

The obtained results indicate an essential contribution of the crustal material at the generation of primary granite melts.

Polar Urals. Granitoids of the rift-related stage. The $\varepsilon \mathrm{Nd}$ values were obtained for A-type granites of the Ochety and Syadatayakha massifs $(+5.6$ and +2.6 ; mantle values), the northern part of the Gerdiz and Ingilor massifs $(+0.7$ and +0.6 , crustal-mantle values). It is also confirmed by the position of composition points of granites of the Gerdiz and Ingilorsky massifs in field A2 of the A1-A2 discriminant diagram, where the contribution of a mantle component is insignificant. The points of granites of the Syadatayakha massif lie in the field A1 with a significant admixture of a mantle component (see Fig. 2, f). The position of the composition point of the Ochety massif with a mantle $\varepsilon \mathrm{Nd}$ value in the A2 field needs to be understood.

Primitive island arc granitoids are illustrated by a single mantle $\varepsilon N d$ value $(+7.4)$ obtained for the Pogurey massif [Estrada et al., 2012] and mature island arc $\varepsilon N d$ values obtained for the Sob massif $(+6.1,+4.1)$ [Udoratina et al., 2003] and small bodies of granitoids of the Lagortayu complex (+5.4) [Estrada et al., 2012].

\subsection{Hf isotope composition}

The relative stability of the Hf isotope system in zircons makes Hf isotopes an important tool for studying the age of a granite melt source and isotope evolution of different rocks. Negative values indicate the participation of the recycled crystal material in the granite melts. In contrast, the positive values indicate the mantle component's role [Amelin et al., 1999; Fujimaki, 1986; Griffin et al., 2002]. We have first studied the Hf isotope composition of zircons from granitoids and have calculated the model ages of massifs of the Polar, Subpolar, and Northern Urals (Suppl. 1; Fig. 5, c).

Polar Urals, Central Uralian megazone, island arc stage. Zircons from plagiogranites (719 Ma, island arc geochemical signatures (I-type)) from the serpentinite mélange zone of the Enganepe Ridge have positive (mantle) $\varepsilon \mathrm{Hf}_{(\mathrm{T})}$ values, varying in a narrow range of $+8.7 \ldots+10.6$. The model age of the granite-producing protolith is $1.2-1.1 \mathrm{Ga}$.

I-type granites of the collisional stage of the southern part of the Gerdiz massif (573 Ma) are characterized by wide variations in crustal-mantle $\mathrm{Hf}$ isotope composition $\left(\varepsilon \mathrm{Hf}_{(\mathrm{T})}\right.$, from -5.84 to +7.52$)$. This is due to the presence of different-aged zircons in the dated zircon association. The model age $\mathrm{T}_{\mathrm{DM} 2}$ of a protolith is $1.72-0.9 \mathrm{Ga}$. The Longotyugan, Taikeu, and Neudachny massifs (605-560 Ma), which have collisional geochemical signatures and belong to the A-type granites, are characterized by mantle $\varepsilon \mathrm{Hf}_{(\mathrm{T})}$ values $(+6-+13)$ and similar model ages ( $\left.\mathrm{T}_{\mathrm{DM} 2}: 1.4-0.76 \mathrm{Ga}\right)$.

Granitoids of the rifting stage (Ingilor, Gerdiz (the northern part), Marunkeu Range, Kharbey massifs; 507-480 Ma) have positive (mantle) $\varepsilon \mathrm{Hf}_{(\mathrm{T})}$ values, varying in a wide range $(+2-+12.5)$; model ages $\mathrm{T}_{\mathrm{DM} 2}$ are in a range of 1.2-0.9 Ga.

Most of the zircons from granitoids of the ore zone of massifs of the central part of the Central Uralian megazone (Longotyugan, Taikeu, Ust-Mramorny) have different model ages and high $\varepsilon \mathrm{Hf}_{\text {(т) }}$ positive values varying from +4.1 to +15.1 (Suppl. 1). All this indicates the influence of a mantle source.

Polar Urals, East Uralian megazone. The age data were obtained only for island arc mature granitoids (granitoids of the Sobsky massif and oligoclasite bodies in ophiolites of the Rai-Iz massif). The $\varepsilon \mathrm{Hf}_{(\mathrm{T})}$ values in granitoids of the Sob massif $(+11.9 \ldots+14.7)$ indicate the mantle (isotope immature) source of the protolith. The calculated model age of the protolith corresponds practically to the age of the origin of granitoids $(0.72-0.47 \mathrm{Ga})$. The close $\varepsilon \mathrm{Hf}_{(\mathrm{T})}$ values $(+13.5 \ldots+15.2)$ were obtained for diorites of the Kongor complex (Dioritovy massif), $\mathrm{T}_{\mathrm{DM} 2}-0.50-0.38 \mathrm{Ga}$ [Sobolev et al., 2017].

The $\varepsilon \mathrm{Hf}_{(\mathrm{T})}$ values for oligoclasites of similar age (382 \pm 2 $\mathrm{Ma})$, developed in the Rai-Iz ophiolites, vary widely from -11.2 to +11.4 . We suggest that these values are determined by the effect of a subduction fluid on the mantle wedge peridotites during the formation of oligoclasite veins [Meng et al., 2018].

Subpolar and Northern Urals. Central Uralian megazone, collisional stage. Zircons of granites of the Vangyr massif (I-type) and Nyarta complex (S-type) were studied. The $\varepsilon \mathrm{Hf}_{\mathrm{T}}$ ) values in granites of the Vangyr massif varying in a range from +1.97 to +6.82 indicate an admixture of the mantle component in the protolith; the model age is 1.76-1.32 Ga. The crustal-mantle $\varepsilon \mathrm{Hf}_{(\mathrm{T})}$ values are typical of granitic gneisses of the Nyarta complex (Suppl. 1; see Fig. 1, b, c (45)), which is also, apparently, associated with the different ages of zircons. For the age of $619 \mathrm{Ma}$, interpreted as the inherited one, the $\varepsilon \mathrm{Hf}_{(\mathrm{T})}$ values are in a range of $-2.09 \ldots+1.76$, which indicates the presence of recycled crustal material during the formation of this-age zircons. The model age is $1.48-1.29 \mathrm{Ga}$. The Hf isotope composition of zircons with an age of $518 \mathrm{Ma}$, considered as the generation time of granitoid magmas, varies in the range +3.58 ... +5.16; the model age is 1.11-1.03 Ga.

Central Uralian megazone, rift-related stage. The A-type granitoids of the Kozhim massif (Suppl. 1; see Fig. 1, b, c (40)) are also characterized by crustal-mantle $\varepsilon \mathrm{Hf}_{(\mathrm{T})}$ values. Zircons are of different ages (485 and $619 \mathrm{Ma}$ ). The $\varepsilon \mathrm{Hf}_{(\mathrm{T})}$ values in zircons with an inherited age of 619 Ma vary from +0.87 to +1.41 ; a granitoid source is crustal-mantle (hybrid, mixed). The model age of the protolith is 1.33-1.31 Ga. Based on studying younger zircons, we consider this age as the time of emplacements of Kozhim massif's granitoids. The 
$\varepsilon \mathrm{Hf}_{(\mathrm{T})}$ values of these zircons are from +2.50 to +3.42 (mantle); the model age is $1.15-1.07 \mathrm{Ga}$.

Northern Urals, Central Uralian megazone, rifting stage. The granitoids of the Mankhambo (522-507 Ma) and Ilyaiz (519-491 Ma) massifs have crustal-mantle characteristics. The $\varepsilon \mathrm{Hf}_{(\mathrm{T})}$ values of the I-type granitoids of the Ilyaiz massif ranging from -2.04 to $+6.74\left(\mathrm{~T}_{\mathrm{DM} 2}, 2.05-1.26 \mathrm{Ga}\right)$ reflect a significant admixture of recycled crustal material in the protolith. The A-type granites of the Mankhambo massif are characterized by a high content of a mantle component during their formation: $\varepsilon \mathrm{Hf}_{(\mathrm{T})},-1.95 \ldots+10.08\left(\mathrm{~T}_{\mathrm{DM} 2}\right.$, 2.05-1.16 Ga).

Early collisional granitoids. The rare-metal granites of the Mankhambo massif are of Early Carboniferous age (336 Ma). The Hf isotope composition of zircons indicates a mantle origin: $\varepsilon \mathrm{Hf}_{(\mathrm{T})}, 0.38 \ldots+6.8$, the model $\mathrm{T}_{\mathrm{DM} 2}$ age is $1.10-0.8 \mathrm{Ga}$ (Suppl. 1; Fig. 5).

\section{DISCUSSION AND CONCLUSIONS}

The granitoid magmatism in the north of the Uralian collisional orogen is represented by products of two large geodynamic stages - Timanides-Preuralides and Uralides. The every stage is characterized by the emplacement of granitoid melts of different petrogeochemical types, which often occur in the same massifs.

Granitoids of the Central Uralian megazone mark the Preuralide (Timanide) evolution of the active margin and Baltica-Arctida collision [Kuznetsov et al., 2007]. The Preuralides are characterized by the change of the island arc magmatism (735-720 Ma; generation of I-type (M-type) granitoids) to the accretionary magmatism (670 Ma, I-type granitoids), and, then, to the collisional (620-520 Ma; simultaneous generation of A-, I -, S-type granitoid melts) and the rift-related magmatism (520-480 Ma; mainly, the generation of A-type granites).

The emplacement of granitoids in the Eastern Ural megazone (Shchuchiya and Voykar-Rai-iz zones) was already associated with the evolution of the Uralian Orogen: the development and closure of the Uralian paleoocean [Biske, 2019; Puchkov, 2010]. Primitive island arc I-type granitoids of the Uralides (460-430 Ma) are followed by mature island arc granitoids (412-368 Ma) and finally by early (360$316 \mathrm{Ma}$ ) and late (277-249 Ma) collisional granitoids.

The distinguished age intervals are confirmed by geodynamic paleoreconstructions of other magmatic complexes of the Urals [Khain et al., 2003; Remizov, 2004; Puchkov, 2010; Sobolev et al., 2018].

The U-Pb zircon age distribution histograms constructed separately for granitoids of the Polar, Subpolar, and Northern Urals (see Fig. 4) show an insignificant shift of the peak of collisional processes, namely, the peak of development of the Protouralide (Timanide) Orogen and its subsequent break-up.

According to the geochronological data available, this peak in the Polar Urals is estimated to be at $525 \mathrm{Ma}$. In the Subpolar Urals, there were two peaks of 625-600 Ma and 550-525 Ma, while in the Northern Urals the peak was at 550-500 Ma. When compiling an integrated U-Pb zircon age distribution histogram for the granitoids of the north of the Urals, the only peak of 550-525 Ma is distinguished.

Thus, the development of the Protouralides-Timanides was a relatively long-term process, lasting from 620 to 520 Ma with a peak at $550 \mathrm{Ma}$. Granitoids of all types (M, S, $\mathrm{I}, \mathrm{A}$ ) lying in this age interval were recognized in the north of the Urals. After the turn of $520 \mathrm{Ma}$, only I- and A-type granites, marking the rift-related stage and the onset of a new tectonic cycle (properly, Uralian), are recognized. The latter is terminated with the formation of the Urals. Composition points of non-collisional I- and A-type granites are confined to the fields of intraplate formations and indicate their origin from a mantle source. The I-type granites, formed already in the Uralian time, are characterized by typical island arc characteristics.

The isotope analysis performed has shown that 0 and $\mathrm{Hf}$ isotope contents in zircons and the whole-rock $\mathrm{Nd}$ content show the variability in the maturity of the protolith of granitoids from the Northern Urals to Polar Urals. The signatures of the most mature recycled material are recorded in the granitoids of the Preuralides of the Northern and Subpolar Urals: $\delta^{18} \mathrm{O}$, from +7.10 to $+8.51 \%, \varepsilon N d=-4.8$ to $-0.3, \varepsilon \mathrm{Hf}_{(\mathrm{T})}=-3.35$ to -1.95 (Suppl. 1). The granitoids of the Preuralides of the Polar Urals are characterized by the presence of mantle-derived components and a more moderate contribution of the crustal material to the primary melts: $\delta^{18} 0$, from +4.7 to $+6.22 \%, \varepsilon N d=+0.6 \ldots+5.6, \varepsilon \mathrm{Hf}_{(\mathrm{TT})}+$ $+2.15 \ldots+15.1$ (Suppl. 1). In general, the model age $\left(\mathrm{T}_{\mathrm{DM} 2}\right)$ of the protolith of granitoids of the Preuralides of the Subpolar $(1.76-1.03 \mathrm{Ga})$ and Northern $(2.09-1.11 \mathrm{Ga})$ Urals is older compared to that of granitoids of the Polar Urals (1.48-0.64 Ga).

Isotope signatures of granitoids of the Uralides record a significant contribution of the mantle component during the petrogenesis: $\delta^{18} 0,+4.19 \ldots+5.69 \%, \varepsilon N d=+4.1 \ldots+7.4$, $\left.\varepsilon \mathrm{Hf}_{(\mathrm{T}}\right)=+8 \ldots+15.7$ (Suppl. 1). The model age $\left(\mathrm{T}_{\mathrm{DM} 2}\right)$ of the protolith for granitoid complexes of the Uralides of the Polar Urals is $1.01-0.37 \mathrm{Ga}$.

Thus, almost all the obtained data $\left(\delta^{18} \mathrm{O}_{\mathrm{zrn}}, \varepsilon \mathrm{Hf}_{(\mathrm{t}) \mathrm{rr} \mathrm{r}^{\prime}} \varepsilon \mathrm{Nd}_{(\mathrm{t}) \mathrm{wr}}\right)$ show a significant contribution of the mantle component to the formation of granitoids of various types in the north of the Urals.

\section{ACKNOWLEDGEMENTS}

The authors are grateful to M.V. Savatenkov (IGGD, Saint Petersburg) for the studies of the Sm-Nd system of granitoids, V.F. Posokhov (GIN SB RAS Ulan-Ude) for studying the isotopic composition of oxygen in zircons of granitoids M.A. Coble (Stanford University, USA) for the possibility of conducting $\mathrm{U}-\mathrm{Pb}$ research, as well as $\mathrm{F}$. Meng and J. Geng (China Academy of Sciences, Beijing and the Tianjin Institute of Geology and Mineral Resources, China) for the opportunity the possibility of studying the Lu-Hf zircon system.

\section{REFERENCES}

Amelin Y., Lee D.-C., Halliday A.N., Pidgeon R.T., 1999. Nature of the Earth's Earliest Crust from Hafnium Isotopes 
in Single Detrital Zircons. Nature 399, 252-255. https:// doi.org/10.1038/20426.

Andreichev V.L., 1999. Isotopic Geochronology of Preuralides of the Subpolar Urals. Scientific Reports. Syktyvkar, 48 p. (in Russian) [Андреичев В.Л. Изотопная геохронология доуралид Приполярного Урала // Научные доклады. Сыктывкар, 1999. 48 с.].

Andreichev V.L., 2010. Geochronology of Granitoid Magmatism of the Subpolar Urals. Bulletin of the Institute of Geology of the Komi Science Center of the Ural Branch of the Russian Academy of Sciences 11, 7-12 (in Russian) [Андреичев В.Л. Геохронология гранитоидного магматизма Приполярного Урала // Вестник Института геологии Коми НЦ УрО РАН. 2010. № 11. С. 7-12].

Andreichev V.L., Kulikova K.V., Larionov A.N., 2012. U-Pb Age of Plagiogranites Malyko (Polar Urals). Bulletin of Komi SC UB RAS 4 (12), 60-66 (in Russian) [Андреичев В.Л., Куликова К.В., Ларионов А.Н. U-Pb возраст плагиогранитов Малыко (Полярный Урал) // Известия Коми НЦ УрО РАН. 2012. Вып. 4 (12). С. 60-66].

Andreichev V.L., Kulikova K.V., Larionov A.N., Sergeev S.A., 2017. Age of Island-Arc Granites in the Shchuch'ya Zone, Polar Urals: First U-Pb (SIMS) Results. Doklady Earth Sciences 477, 1260-1264. https://doi.org/10.1134/S10283 34X17110095.

Andreichev V.L., Larionov A.N., Litvinenko A.F., 2007. New $\mathrm{Rb}-\mathrm{Sr}$ and $\mathrm{U}-\mathrm{Pb}$ Data on the Age of Granitoids of the Syadatayakhay Intrusion (Polar Urals). Lithosphere 1, 147154 (in Russian) [Андреичев В.Л., Ларионов А.Н., Литвиненко A.Ф. Новые $\mathrm{Rb}-\mathrm{Sr}$ и U-Pb данные о возрасте гранитоидов Сядатаяхинской интрузии (Полярный Урал) // Литосфера. 2007. № 1. С. 147-154].

Berland N.G., 1982. Zoning of the Urals by the Type of Structure of the Earth's Crust. Soviet Geology 11, 78-89 (in Russian) [Берлянд Н.Г. Районирование Урала по типу строения земной коры // Советская геология. 1982. № 11. C. 78-89].

Biske Yu.S., 2019. Geology of Russia. St. Petersburg University Press, Saint Petersburg, 228 p. (in Russian) [Бискэ Ю.С. Геология России. СПб.: Изд-во СПбГУ, 2019. 228 с.].

Chappell B.W., White A.I.R., 1974. Two Contrasting Granite Types. Pacific Geology 8, 173-174.

Chervyakovsky S.G., Ivanov V.N., Kurzanov I.Yu., Kuzenkov N.A., Ronkin Yu.L., 1992. On the Age Position of the Malopatoksky Massif of Granitoids in the Subpolar Urals and Its Formation Affiliation In: Informational Collection of Scientific Papers of IGG UB RAS. Yearbook 1991. IGG UB RAS, Ekaterinburg, p. 71-74 (in Russian) [Червяковский С.Г., Иванов В.Н., Курзанов И.Ю., Кузенков Н.А., Ронкин Ю.Л. О возрастной позиции Малопатокского массива гранитоидов на Приполярном Урале и его формационной принадлежности // Информационный сборник научных трудов ИГГ УрО РАН. Ежегодник-1991 ИГГ УрО РАН. Екатеринбург, 1992. С. 71-74].

Demonterova E.I., Ivanov A.V., Karmanov N.S., Palessky S.V., Posokhov V.F., 2012. Neoproterozoic Metaterrigenous Rocks of the North Muya Block (Baikal-Mui Belt): New Data on the Petrochemical Composition. In: Geodynamic
Evolution of the Lithosphere of the Central Asian Mobile Belt (from Ocean to Continent). Proceedings of Scientific Meeting (October 17-20, 2012). Iss. 10. Vol. 1. IEC SB RAS, Irkutsk, p. 78-79 (in Russian) [Демонтерова Е.И., Иванов А.В., Карманов Н.С., Палесский С.В., Посохов В.Ф. Неопротерозойские метатерригенные породы СевероМуйской глыбы (Байкало-Муйский пояс): новые данные по петрохимическому составу // Геодинамическая эволюция литосферы Центрально-Азиатского подвижного пояса (от океана к континенту): Материалы научного совещания по Программе фундаментальных исследований ОНЗ РАН (17-20 октября 2012 г.). Иркутск: ИЗК СО РАН, 2012. Вып. 10. Т. 1. С. 78-79].

Dushin V.A., 2017. Magmatism and Metallogeny of the Transverse Structures of the North Urals. News of the Ural State Mining University 3 (47), 7-16 (in Russian) [Душин B.A. Магматизм и металлогения поперечных структур Уральского севера // Известия УГГУ. 2017 Вып. 3. № 47. С. 7-16]. https://doi.org/10.21440/2307-2091-2017-3-7-16.

Dushin V.A., Faust A.V., 2008. Riphean Granite Magmatism and Metallogeny of the Manhambov Block. Regional Geology and Metallogeny 35, 28-33 (in Russian) [Дyшин В.А., Фауст А.В. Рифейский гранитный магматизм и металлогения Маньхамбовского блока // Региональная геология и металлогения. СПб.: ВСЕГЕИ, 2008. № 35. C. 28-33].

Dushin V.A., Kozmin V.S., Serdyukova O.P., Nikulina I.A., Kolganov E.R., 2012. Geology and Complex Rare-Metal-UraniumThorium Mineralization of the Manhambov Block (Subpolar Urals). Lithosphere 2, 166-172 (in Russian) [Душин B.A., Козьмин В.С., Сердюкова О.П., Никулина И.А., Колганов Е.Р. Геология и комплексное редкометалльно-уран-ториевое оруденение Маньхамбовского блока (Приполярный Урал) // Литосфера. 2012. № 2. С. 166-172].

Eby G.N., 1992. Chemical Subdivision of the A-Type Granitoids: Petrogenetic and Tectonic Implications. Geology 20 (7), 641-644. https://doi.org/10.1130/0091-7613(1992) 020\%3C0641:CSOTAT\%3E2.3.CO;2.

Estrada S., Henjes-Kunst F., Burgath K.-P., Roland N.W., Schafer F., Khain E.N., Remizov D.N., 2012. Insights into Magmatic and Geotectonic History of the Voikar Massif, Polar Urals. Zeitschrift der Deutschen Gesellschaft für Geowissenschaften 163 (1), 9-41. https://doi.org/10.1127/18601804/2012/0163-0009.

Fujimaki H., 1986. Partition Coefficients of Hf, Zr, and REE between Zircon, Apatite, and Liquid. Contributions to Mineralogy and Petrology 94, 42-45. https://doi.org/10. 1007/BF00371224.

Geng J.-Z., Li H.K., Zhang J., Zhou H.-Y., Li H.-M., 2011. Zircon Hf Isotope Analysis by Means of LA-ICP-MS. Geological Bulletin of China 30,1508-1513. (in Chinese with English abstract).

Goldin B.A., Kalinin E.P., Puchkov V.N., 1981. Genetic Types of Granites in the North of the Urals and Patterns of Their Distribution. In: Questions of Petrology and Metallogeny of the Urals. Abstracts of the IV Ural Petrographic Conference. Vol. II. Sverdlovsk, p. 52-53 (in Russian) [Голдин Б.А., Калинин Е.П., Пучков В.Н. Генетические типы гранитов 
севера Урала и закономерности их размещения // Вопросы петрологии и металлогении Урала: Тезисы докладов IV Уральской петрографической конференции. Свердловск, 1981. T. II. C. 52-53].

Goldin B.A., Kalinin E.P., Puchkov V.N., 1999. Magmatic Formations of the Western Slope of the North Urals and Their Mineralogy. Syktyvkar, 213 p. (in Russian) [Голдин В.А., Калинин Е.П., Пучков В.Н. Магматические формации западного склона севера Урала и их минерагения. Сыктывкар, 1999. 213 с.].

Golubeva I.I., 2011. The First Results of U-Pb Dating of Zircons from Gneissic Granites of the Kharbei Complex (Polar Urals). Doklady Earth Sciences 439, 1048. https://doi. org/10.1134/S1028334X11080022.

Grebennikov A.V., 2014. A-Type Granites and Related Rocks: Petrogenesis and Classification. Russian Geology and Geophysics 55 (11), 1353-1366. https://doi.org/10.1016/ j.rgg.2014.10.011.

Griffin W.L., Wang X., Jackson S.E., Pearson N.J., O’Reilly S.Y., Xu X., Zhou X., 2002. Zircon Chemistry and Magma Genesis, SE China: In-Situ Analysis of Hf Isotopes, Pingtan and Tonglu Igneous Complexes. Lithos 61 (3-4), 237-269. https://doi. org/10.1016/S0024-4937(02)00082-8.

Harris N.B.W., Pearce J.A., Tindle A.G., 1986. Geochemical Characteristics of Collision-Zone Magmatism. In: M.P. Coward, A.C. Ries (Eds), Collision Tectonics. Geological Society of London Special Publication 19, 67-81. https://doi. org/10.1144/GSL.SP.1986.019.01.04.

Khain E.V., Bibikova E.V., Salnikova E.B., Kröner A., Gibsher A.S., Didenko A.N., Degtyarev K.E., Fedotova A.A., 2003. The Palaeo-Asian Ocean in the Neoproterozoic and Early Paleozoic: New Geochronologic Data and Paleotectonic Reconstructions. Precambrian Research 122 (1-2), 329-358. https://doi.org/10.1016/S0301-9268(02)00218-8.

Khain E.V., Fedotova A.A., Bibikova E.V., Salnikova E.B., Kotov A.B., Burgat K.P., Kovach V.P., Remizov D.N., 2005. The Neoproterozoic and Early Paleozoic Geologic History of the Ural-Kazakhstan Margin of the Paleoasian Ocean Using New Isotopic and Geochronologic Data Obtained for the Polar Ural's Region. Russian Journal of Earth Sciences 7, ES5003. https://doi.org/10.2205/2005ES000188.

Khain E.V., Sal'nikova E.B., Kotov A.B., Burgath K.P., Fedotova A.A., Kovach V.P., Yakovleva S.Z., Remizov D.N., Schaefer F., 2008. U-Pb Age of Plagiogranites from the Ophiolite Association in the Voikar-Synya Massif, Polar Urals. Doklady Earth Science 419, 392-396. https://doi.org/10.1134/S1 028334 X08030082.

Kheraskov N.P., 1948. The Principles of Compiling Tectonic Maps of the Folded Areas of the Southern Urals. Bulletin of the USSR Academy of Sciences. Geological Series 5, 121-134 (in Russian) [Херасков Н.П. Принципы составления тектонических карт складчатых областей Южного Урала // Известия АН СССР. Серия геологическая. 1948. № 5. C. 121-134].

Kheraskov N.P., Perfilyev A.S., 1963. The Main Features of the Geosynclinal Structures of the Urals. Problems of Regional Tectonics of the USSR. Publishing House of the USSR Academy of Science, Moscow, 35-63 (in Russian)
[Херасков Н.П., Перфильев А.С. Основные особенности геосинклинальных структур Урала // Проблемы региональной тектоники СССР. М.: Изд-во АН СССР, 1963. C. 35-63].

Korovko A.V., Shardakova G.Yu., Puchkov V.N., Khubanov V.B., 2019. Vendian - Early Cambrian Granites of the Krutorechensky Complex (Northern Urals, Russia): Protolith Age, Geodynamic Conditions of Generation and Transformation. Geodynamics \& Tectonophysics 10 (4), 863-878 (in Russian) [Коровко А.В., Шардакова Г.Ю., Пучков В.Н., Хубанов В.Б. Венд-раннекембрийские граниты крутореченского комплекса (Присалатимская зона, Северный Урал): возраст протолита, геодинамические условия образования и преобразования // Геодинамика и тектонофизика. 2019. Т. 10. № 4. С. 863-878]. https:// doi.org/10.5800/GT-2019-10-4-0446.

Krupenik V.A., Sveshnikova K.Yu., Remizov D.N. et al., 2013. A Detailed Study of the Yangyugansk Parametric Well Section and Integrated Processing and Interpretation of Materials from Surface and Borehole Geological and Geophysical Works. (Stage 2. Drilling a Well to a Depth of $4000 \mathrm{~m}$ ). VSEGEI Publishing House, Saint Petersburg, 2672 p. (in Russian) [Крупеник В.А., Свешникова К.Ю., Ремизов Д.Н. и др. Детальное изучение разреза Янгиюганской параметрической скважины и комплексная обработка и интерпретация материалов наземных и скважинных геолого-геофизических работ. (Этап 2. Бурение скважины до глубины 4000 м). СПб.: Изд-во ВСЕГЕИ, 2013. 2672 c.].

Kulikova K.V., Soboleva A.A., Udoratina O.V., Grove M., 2012. Age of Metagranitoids of the Eclogite-Gneiss Complex of the Marunkeu Ridge (Polar Urals). In: Geodynamics, Ore Deposits and the Deep Structure of the Lithosphere. XV Readings in memory of Academician A.N. Zavaritsky. Proceedings of the Materials of the All-Russian Scientific Conference with International Participation (September 1114, 2012). Publishing House of IGG UB RAS, Ekaterinburg, p. 155-157 (in Russian) [Куликова К.В., Соболева А.А., Удоратина О.В., Гроув М. Возраст метагранитоидов эклогит-гнейсового комплекса хребта Марункеу (Полярный Урал) // XV Чтения памяти академика А.Н. Заварицкого: Геодинамика, рудные месторождения и глубинное строение литосферы: Материалы Всероссийской научной конференции с международным участием (1114 сентября 2012 г.). Екатеринбург: ИГГ УрО РАН, 2012. C. 155-157].

Kuzenkov N.A., Soboleva A.A., Matukov D.I., 2004. The Age of Intrusive Formations of the Tynagot Region (Subpolar Urals) According to Isotopic Dating of Single Zircon Crystals. In: Geology and Mineral Resources of the European North-East of Russia. Proceedings of the Materials of the XIV Geological Congress of the Republic of Komi (April 13-16, 2004). Vol. II. Geoprint, Syktyvkar, p. 98-102 (in Russian) [Кузенков Н.А., Соболева А.А., Матуков Д.И. Возраст интрузивных образований Тынаготского района (Приполярный Урал) по данным изотопного датирования единичных кристаллов циркона // Геология и минеральные ресурсы Европейского северо-востока 
России: Материалы XIV Геологического съезда Республики Коми (13-16 апреля 2004 г.). Сыктывкар: Геопринт, 2004. T. II. C. 98-102].

Kuzenkov N.A., Soboleva A.A., Rodionov N.V., Larionov A.N., 2005. The Panechaiz Diorite-Tonalite Complex of the Lyapinsky Structural-Formation Zone of "Preuralides" (Subpolar Urals): Compositional Features and Age. In: Origin of Igneous Rocks. Proceedings of the Materials of the International (X All-Russian) Petrographic Meeting "Petrography of the XXI Century" (June 20-22, 2005). Publishing House of the Kola Science Centre of RAS, Apatity, p. 128-130 (in Russian) [Кузенков Н.А., Соболева А.А., Родионов Н.В., Ларионов А.Н. Панэчаизский диорит-тоналитовый комплекс Ляпинской структурно-формационной зоны «доуралид» (Приполярный Урал): особенности состава и возраст // Происхождение магматических пород: Материалы международного (Х Всероссийского) петрографического совещания «Петрография XXI века» (20-22 июня 2005 г.). Апатиты: Изд-во КНЦ РАН, 2005. С. 128-130].

Kuznetsov N.B., Soboleva A.A., Miller E.L., Udoratina O.V., Gehrels G., Romanyuk T.V., 2013. First U-Pb Datings of Detrital Zircons from Middle and Upper Paleozoic Sandstones of the Polar Urals: Testing the Regional Tectonic Models. Doklady Earth Sciences 451, 692-697. https: //doi.org/10. 1134/S1028334X1307012X.

Kuznetsov N.B., Soboleva A.A., Udoratina O.V., Andreichev V.L., Hertseva M.V., 2007. Pre-Ordovician Tectonic Evolution and Volcano-Plutonic Associations of the Timanides and Northern Pre-Uralides. Northeast Part of the East Europian Craton. Gondwana Research 12 (3), 305-323. https:// doi.org/10.1016/j.gr.2006.10.021.

Kuznetsov N.B., Soboleva A.A., Udoratina O.V., Gertseva M.V., 2005a. Pre-Ordovician Granitoids of the TimanUral Region and the Evolution of Protouralides-Timanides. Geoprint, Syktyvkar, 100 p. (in Russian) [Кузнецов Н.Б., Соболева А.А., Удоратина О.В., Герцева М.В. Доордовикские гранитоиды Тимано-Уральского региона и эволюция протоуралид-тиманид. Сыктывкар: Геопринт, 2005. 100 c.].

Kuznetsov N.B., Soboleva A.A., Udoratina O.V., Gertseva M.V., Andreichev V.L., Dorokhov N.S., 2005b. Formation of Pre-Ordovician Volcanoplutonic Associations of the North Ural-Timan-Pechora Region and Proto-Ural Evolution of the North-Eastern Outskirts of the East European Paleocontinent. Proceedings of the Geological Institute. Essays on Regional Tectonics. Kazakhstan, Tien Shan, Polar Urals. Iss. 561. Vol. 2. P. 158-200 (in Russian) [Кузнецов Н.Б., Соболева А.А., Удоратина О.В., Герцева М.В., Андреичев В.Л., Дорохов Н.С. Формирование доордовикских вулканоплутонических ассоциаций Североуральско-Тимано-Печорского региона и протоуральская эволюция северо-восточной окраины Восточно-Европейского палеоконтинента // Труды Геологического института. Очерки по региональной тектонике: Казахстан, Тянь-Шань, Полярный Урал. М.: Наука, 2005. Вып. 561. Т. 2. С. 158-200].

Kuznetsov N.B., Udoratina O.V., 2007. Age and Geodynamic Conditions for the Formation of Late Precambrian Granitoids of the Vangyr Massif, Subpolar Ural. Bulletin of
Moscow Society of Naturalists. Geological Section 82 (2), 3-12 (in Russian) [Кузнецов Н.Б., Удоратина О.В. Возраст и геодинамические условия формирования позднедокембрийских гранитоидов Вангырского массива, Приполярный Урал // Бюллетень МОИП. Отдел геологический. 2007. Т. 82. Вып. 2. С. 3-12].

Makhlaev L.V., 1996. Granitoids of the North of the Central Ural Uplift (Polar and Subpolar Urals). Ekaterinburg, 150 p. (in Russian) [Махлаев Л.В. Гранитоиды севера Центрально-Уральского поднятия (Полярный и Приполярный Урал). Екатеринбург, 1996. 150 с.].

Makhlaev L.V., Golubeva I.I., Remizov D.N., Soboleva A.A., 2005. Granitoids of the North of the Urals: Systematics, Geodynamic Position, Age. In: Evolution of Petrogenesis and Differentiation of the Earth's Matter. Proceedings of the Materials of the International Petrographic Meeting "Petrography of the XXI Century" (June 20-22, 2005). Publishing House of the Kola Science Centre of RAS. Apatity, p. 140-142 (in Russian) [Махлаев Л.В., Голубева И.И., Ремизов Д.Н., Соболева А.А. Гранитоиды севера Урала: систематика, геодинамическая позиция, возраст // Эволюция петрогенеза и дифференциация вещества Земли: Материалы международного (Х Всероссийского) петрографического совещания «Петрография XXI века» (20-22 июня 2005 г.). Апатиты: Изд-во КНЦ РАН, 2005. C. 140-142].

Maniar P.D., Piccoli P.M., 1989. Tectonic Discriminations of Granitoids. Geological Society of America Bulletin 101 (5), 635-643. https://doi.org/10.1130/0016-7606(1989) 101\%3C0635:TD0G\%3E2.3.CO;2.

Melgunov A.N. et al., 2008. Predictive Assessment of the Resource Potential of the Northern, Subpolar and Polar Urals on the Basis of Modern Geological and Geophysical, Mineralogenic, Geochemical and Isotopic Research Methods. Geological Report on the Object 4-1.05. VSEGEI Publishing House, Saint Petersburg, 702 p. (in Russian) [Мельгунов А.Н. и др. Прогнозная оценка ресурсного потенциала Северного, Приполярного и Полярного Урала на основе современных геолого-геофизических, минерагенических, геохимических и изотопных методов исследований. Геологический отчет по объекту 4-1.05. СПб.: Изд-во ВСЕГЕИ, 2008. 702 с.].

Melgunov A.N., Morozov A.F., Vodolazskaya V.P., Zhdanov A.V., Berlyand N.G., Vernik I.I., Denisov V.A., Dushin V.A., Kazak A.P., Kashubin S.N. et al., 2010. The Main Features of the Geological Structure and Mineral and Raw Material Potential of the Northern, Subpolar and Polar Urals. VSEGEI Publishing House, Saint Petersburg, 274 p. (in Russian) [Мельгунов А.Н., Водолазская В.П., Жданов А.В., Берлянд Н.Г., Мельгунов А.Н., Морозов А.Ф., Водолазская В.П., Жданов А.В., Берлянд Н.Г., Верник И.И., Денисов В.А., Душин В.А., Казак А.П., Кашубин С.Н. и др. Основные черты геологического строения и минерально-сырьевой потенциал Северного, Приполярного и Полярного Урала. СПб.: Изд-во ВСЕГЕИ, 2010. 274 с.].

Meng F., Shmelev V.R., Kulikova K.V., Ren Y., 2018. A RedCorundum-Bearing Vein in the Rai-Iz Ultramafic Rocks, Polar Urals, Russia: The Product of Fluid Activity in a Subduction 
Zone. Lithos 320-321. https://doi.org/10.1016/j.lithos. 2018.09.025.

Morgunova A.A., Soboleva A.A., 2007. Relics of the Root Part of the Post-Riphean Primitive Island Arc in the North of the Enganape Uplift (Polar Urals). Bulletin of the Institute of Geology of the Komi Science Center of the Ural Branch of the Russian Academy of Sciences 12, 13-18 (in Russian) [Моргунова А.А., Соболева А.А. Реликты корневой части позлнерифейской примитивной островной дуги на севере Поднятия Енганапэ (Полярный Урал) // Вестник ИГ Коми НЦ УрО РАН. 2007. № 12. С. 13-18].

O'Connor J.T., 1965. A Classification for Quartz-Rich Igneous Rock Based on Feldspar Ratios. United States Geological Survey 525 (2), B79-B84.

Okhotnikov V.N., Mizin V.I., Belyakova L.T. et al., 1985. Correlation of Magmatic Complexes in the European Northeast of the USSR. Syktyvkar, 25 p. (in Russian) [Охотников B.H., Мизин В.И., Белякова Л.Т. и др. Корреляция магматических комплексов европейского северо-востока СССР. Сыктывкар, 1985. 25 с.].

Pearce J.A., Harris N.B.W., Tindle A.G., 1984. Trace Element Discrimination Diagrams for the Tectonic Interpretation of Granitic Rocks. Journal of Petrology 25 (4), 956983. https://doi.org/10.1093/petrology/25.4.956.

Peccerilo A., Taylor S.R., 1976. Geochemistry of Eocene Calc-Alkaline Volcanic Rock from the Kastamonu Area, Northern Turkey. Contributions to Mineralogy and Petrology 58, 63-81. https://doi.org/10.1007/BF00384745.

Petrov G.A., Ronkin Yu.L., Gerdes A., Maslov A.V., 2014a. New Data on the Composition and Age of the Complexes of the Pre-Paleozoic Base of the Tagil Paleoisland-Arc System in the Northern Urals. Doklady Earth Sciences 459 (5), 589594 (in Russian) [Петров Г.А., Ронкин Ю.Л., Гердес А., Маслов А.В. Новые данные о составе и возрасте комплексов допалеозойского основания Тагильской палеоостроводужной системы на Северном Урале // Доклады АН. 2014. T. 459. № 5. C. 589-594]. https://doi.org/10.7868/ S0869565214350217.

Petrov G.A., Ronkin Yu.L., Gerdes A., Maslov A.V., 2017. New Data Concerning the Age and Specific of Magmatism of Timanides in Southern Part of Lyapin Structure (Northern Urals). Doklady Earth Sciences 476 (4), 426-430 (in Russian) [Петров Г.А., Ронкин Ю.Л., Гердес А., Маслов А.В. Новые данные о возрасте и специфике магматизма тиманид южной части Ляпинской структуры (Северный Урал) // Доклады АН. 2017. Т. 476. № 4. C. 426-430]. https://doi. org/10.7868/S0869565217280155.

Petrov G.A., Ronkin Yu.L., Maslov A.V., 2016. Late Proterozoic and Early Paleozoic Igneous Formations of the Southern Part of the Lyapin-Kutim Anticlinorium (Northern Urals). In: Petrology of Igneous and Metamorphic Formations. Proceedings of the Materials of the All-Russian Petrographic Conference with International Participation (November 29 December 2, 2016). Iss. 8. Publishing House of Tomsk CSTI, Tomsk, p. 284-288 (in Russian) [Петров Г.А., Ронкин Ю.Л., Маслов А.В. Позднепротерозойские и раннепалеозойские магматические формации южной части Ляпинского-Кутимского антиклинория (Северный Урал) //
Петрология магматических и метаморфических формаций: Материалы Всероссийской петрографической конференции с международным участием (29 ноября 2 декабря 2016 г.). Томск: Изд-во Томского ЦНТИ. 2016. Вып. 8. С. 284-288].

Petrov G.A., Ronkin Y.L., Maslov A.V., Gerdes A., Il'yasova G.A., Tristan N.I., Sindern S., 2013. New Data on the Composition and Age of Orogenic Granitoids from Timanides of the North Urals. Doklady Earth Sciences 450, 618-622. https://doi.org/10.1134/S1028334X13060202.

Petrov G.A., Ronkin Yu.L., Tristan N.I., Gerdes A., Maslov A.V., 2014b. New Data on the Composition and Age of Granites of the Isherim Anticlinorium and the Position of the Tymanid Boundary in the Northern Urals. Doklady Earth Sciences 459 (6), 721-725 (in Russian) [Петров Г.А., Ронкин Ю.Л., Тристан Н.И., Гердес А., Маслов А.В. Новые данные о составе и возрасте гранитов Ишеримского антиклинория и положение границы тиманид на Северном Урале // Доклады АН. 2014. Т. 459. № 6. C. 721-725]. https://doi.org/10.7868/S08695652143 60201.

Petrov O.V. (Ed.), 2016. Geological Map of Russia and Adjacent Water Areas. Scale 1:2500000. VSEGEI Publishing House, Saint Petersburg (in Russian) [Геологическая карта России и прилегающих акваторий. Масштаб 1:2500000 / Ред. О.В. Петров. СПб.: Изд-во ВСЕГЕИ, 2016].

Puchkov V.N., 2010. Geology of the Urals and Cis-Urals (Actual Issues of Stratigraphy, Tectonics, Geodynamics and Metallogeny). DizaynPoligrafServis, Ufa, 280 p. (in Russian) [Пучков В.Н. Геология Урала и Приуралья (актуальные вопросы стратиграфии, тектоники, геоднамики и металлогении). Уфа: ДизайнПолиграфСервис, 2010. 280 с.].

Pystin A.M., Andreichev V.L., Udoratina O.V. et al., 2011. The Deep Structure of the Timan-North Ural Region. Geoprint, Syktyvkar, 242 p (in Russian) [Пыстин A.М., Андреичев В.Л., Удоратина О.В. и др. Глубинное строение Тимано-Североуральского региона. Сыктывкар: Геопринт, 2011. 261 c.].

Pystin A.M., Pystina Yu.I., 2008. Metamorphism and Granite Formation in the Proterozoic - Early Paleozoic History of the Formation of the Subpolar Segment of the Earth's Crust. Lithosphere (6), 25-38 (in Russian) [Пыстин A.М., Пыстина Ю.И. Метаморфизм и гранитообразование в протерозойско-раннепалеозойской истории формирования Приполярноуральского сегмента земной коры // Литосфера. 2008. № 6. C. 25-38].

Pystin A.M., Pystina Yu.I., 2011. New Data on the Age of Granitoids of the Subpolar Urals in Connection with the Problem of Isolating the Kozhim Mid-Riphean Granite-Rhyolite Formation. Bulletin of Komi SC UB RAS 4 (8), 73-78 (in Russian) [Пыстин А.М., Пыстина Ю.И. Новые данные о возрасте гранитоидов Приполярного Урала в связи с проблемой выделения кожимской среднерифейской гранит-риолитовой формации // Известия Коми НЦ Ур0 РАН. 2011. Вып. 4 (8). С. 73-78].

Pystin A.M., Pystina Yu.I., 2019. The Precambrian in the Sub-Polar Urals: The Chronostratigraphic Aspect. Proceedings of Karelian SC RAS 2, 34-52 (in Russian) [Пыстин A.M., 
Пыстина Ю.И. Докембрий Приполярного Урала: хроностратиграфический аспект // Труды Карельского НЦ РАН. 2019. № 2. C 34-52]. https://doi.org/10.17076/geo904.

Queiroga G., Martins M., Kuznetsov N., Chemale F.Jr., Dussin I., Pedrosa-Soares A.C., Kulikova K., de Castro M.P., 2016. Timing of Lower Crust Generation in the Voykar Ophiolite Massif, Polar Urals, Russia: U-Pb (LA-ICP-MS) Data from Plagiogranite Zircons. Ofioliti 41 (2), 75-84. https://doi. org/10.4454/ofioliti.v41i2.443.

Remizov D.N., 2004. Island-Arc System of the Polar Urals (Petrology and Evolution of Deep Zones). Publishing House of the Ural Branch of the RAS, Ekaterinburg, 221 р. [Ремизов Д.Н. Островодужная система Полярного Урала (петрология и эволюция глубинных зон). Екатеринбург: УрО РАН, 2004. 221 с.].

Remizov D.N., Kulikova K.V., Sychev S.N., Nosikov M.V., Sergeev S.A., 2012. U-Pb Dating of Zircons from Plagiogranites of the Lagorta Yu Dike Complex (Polar Urals). Doklady Earth Sciences 447, 1289-1291. https://doi.org/10.1134/ S1028334X12120124.

Saltykova T.E., Proskurin V.F., Makaryev L.B. et al., 2008. Geological Report on the Results of Work on the Object "Isotope-Geochemical and Geochronological Support of State Geological Mapping at a Scale of 1:1000000". VSEGEI Publishing House, Saint Petersburg, 2776 р.) (in Russian) [Салтыкова Т.Е., Проскурин В.Ф., Макарьев Л.Б. и др. Геологический отчет о результатах работ по объекту «Изотопно-геохимическое и геохронологическое обеспечение государственного геологического картирования масштаба 1:1000000». СПб.: Изд-во ВСЕГЕИ, 2008. 2776 с.].

Savatenkov V.M., Morozova I.M., Levskiy L.K., 2004. Behavior of the Sm-Nd, Rb-Sr, K-Ar, and U-Pb Isotopic Systems during Alkaline Metasomatism: Fenites in the OuterContact Zone of an Ultramafic-Alkaline Intrusion. Geochemistry International 42 (10), 899-920.

Shadrin A.N., Sobolev I.D., 2017. Results of Geochronological Studies of Igneous Rocks of the Sibileyskaya Area (Eastern Slope of the Polar Urals). Gornyye Vedomosti 2 (150), 54-69 (in Russian) [Шадрин А.Н., Соболев И.Д. Результаты геохронологических исследований магматических пород Сибилейской площади (Восточный склон Полярного Урала) // Горные ведомости. 2017. № 2 (150). C. 54-69].

Shishkin M.A., Shkarubo S.I., Markina N.M. et al., 2009. The Main Results of Creating a Set of State Geological Maps 1:1000000 (Third Generation). Sheet R-41 (Amderma). In: Geology and Mineral Resources of the European North-East of Russia: Proceedings of the XV Geological Congress of the Republic of Komi (April 13-16, 2009). Vol. II. Institute of Geology of Komi SC UB RAS, Syktyvkar, p. 183-185 (in Russian) [Шишкин М.A., Шкарубо С.И., Маркина Н.М. и др. Основные итоги создания комплекта государственной геологической карты масштаба 1:1000000 (3-е поколение). Лист R-41 (Амдерма) // Геология и минеральные ресурсы Европейского северо-востока России: Материалы XV Геологического съезда Республики Коми (1316 апреля 2009 г.). Сыктывкар: ИГ Коми НЦ УрО РАН, 2009. T. II. C. 183-185].
Shteinberg D.S., Vigorova V.G., 1976. Deep and Hypabyssal Granites in the Central Ural Uplift in the Subpolar Urals. Magmatism, Metamorphism, Metallogeny of the Western Slope of the Urals. Ufa, p. 100-106 (in Russian) [Штейнберг Д.С., Вигорова В.Г. Глубинные и гипабиссальные граниты в Центрально-Уральском поднятии на Приполярном Урале // Магматизм, метаморфизм, металлогения западного склона Урала. Уфа, 1976. С. 100-106].

Shuyskiy A.S., Udoratina O.V., Coble M.A., 2020. Granites of the Gerdiz Massif, South Part (Polar Urals): U-Pb (SIMS) Data. Proceedings of the Fersmanov Scientific Session of the Kola SC RAS 17, 568-572 (in Russian) [Шуйский A.C., Удоратина O.В., Кобл М.А. Гердизский массив, южная часть (Полярный Урал): U-Pb (SIMS) данные // Труды Ферсмановской научной сессии ГИ КНЦ РАН. 2020. Т. 17. C. 568-572]. https://doi.org/10.31241/FNS.2020.17.110.

Shuyskiy A.S., Udoratina O.V., Miller E.L., Coble M.A., 2015. Metagranitoids of the Ingilorsky Massif (Polar Urals): U-Pb Data. Proceedings of the IV International Scientific Practical Conference of Young Scientists and Specialists Devoted to Academician A.P. Karpinsky's Memory (February 16-20, 2015). VSEGEI Publishing House, Saint Petersburg, 481-485 (in Russian) [Шуйский A.C., Удоратина О.В., Миллер Е.Л., Кобл М. Метагранитоиды Ингилорского массива (Полярный Урал): U-Pb данные // Материалы IV Международной научно-практической конференции молодых ученых и специалистов памяти академика А.П. Карпинского (16-20 февраля 2015 г.). СПб.: Изд-во ВСЕГЕИ, 2015. C. 481-485].

Shuyskiy A.S., Udoratina O.V., Miller E.L., Coble M.A., 2018. Granites of the Gerdiz Massif (Polar Urals): New Data. Vestnik of the Institute of Geology of the Komi Science Center UB RAS 12, 23-30. https://doi.org/10.19110/2221-1381-20 18-12-23-30.

Sobolev I.D., Shadrin A.N., Rastorguev V.A., Kozyreva D.A., 2017. Early Island Arc Granitoids of the Shchuchinsky Zone of the Polar Urals (Results of U-Pb (SIMS) Dating of Zircons). Moscow University Geology Bulletin. Geology 1, 22-32 (in Russian) [Соболев И.Д., Шадрин А.Н., Расторгуев В.А., Козырева Д.А. Раннеостроводужные гранитоиды Щучьинской зоны Полярного Урала (результаты U-Pb (SIMS) датирования цирконов) // Вестник Московского университета. Геология. 2017. № 1. С. 22-32].

Sobolev I.D., Soboleva A.A., Udoratina O.V., Varlamov D.A., Hourigan J.K., Khubanov V.B., Buyantuev M.D., Soboleva D.A., 2018. Devonian Island-Arc Magmatism of the Voikar Zone in the Polar Urals. Geotectonics 52, 531-563. https://doi. org/10.1134/S0016852118050060.

Soboleva A.A., 2020. Results of U-Pb (SIMS) - Dating of Zircon from Granites and Rhyolites Maldynyrd Ridge, Subpolar Ural. In: Modern Problems of Theoretical, Experimental and Applied Mineralogy (Yushkin's Readings 2020). Proceedings of Russian Conference with International Participation (December 7-10, 2012). Geoprint, Syktyvkar, 63-65 (in Russian) [Соболева А.А. Результаты U-Pb (SIMS) - датирования циркона из гранитов и риолитов хр. Малдынырд, Приполярный Урал // Современные проблемы теоретической, экспериментальной и прикладной 
минералогии (Юшкинские чтения 2020): Материалы российской конференции с международным участием (7-10 декабря 2020 г.). Сыктывкар: Геопринт, 2020. C. 63-65].

Soboleva A.A., Andreichev V.L., Larionov A.N., Koble M.A., Miller E.L., 2016. Age of the Lapchavozh Volcano-Plutonic Association According to the Results of U-Pb (SIMS) Dating of Zircons. In: Geological Processes in the Conditions of Subduction, Collision and Sliding of Lithospheric Plates. Proceedings of Third All-Russian Conference with International Participation (September 20-23, 2016). Dalnauka, Vladivostok, p. 235-236 (in Russian) [Соболева А.А., Андреичев В.Л., Ларионов А.Н., Кобл М.А., Миллер Э.Л. Возраст лапчавожской вулкано-плутонической ассоциации по результатам U-Pb (SIMS) датирования цирконов // Геологические процессы в обстановках субдукции, коллизии и скольжения литосферных плит: Материалы третьей Всероссийской конференции с международным участием (20-23 сентября 2016 г.). Владивосток: Дальнаука, 2016. C. 235-236].

Soboleva A.A., Karchevskii A.F., Efanova L.I., Kuznetsov N.B., Grove M., Sobolev I.D., Maurin M.V., 2012. Evidence for Late Riphean Granite Formation in the Polar Urals. Doklady Earth Sciences 442, 181-187. https://doi.org/10.1134/S102833 4X12020080.

Soboleva A.A., Kudryashov N.M., Dorokhov N.S., 2004a. The U-Pb age of Granitoids from the Naroda Pluton, the NearPolar Urals. Doklady Earth Sciences 397 (6), 804-808.

Soboleva A.A., Kuzenkov N.A., Udoratina O.V., 2005a. Age of Zircons from Granites of the Core of the Khobeiz GraniteGneiss Dome (Subpolar Ural). In: Origin of Igneous Rocks. Proceedings of the Materials of the International X All-Russian Petrographic Meeting (June 20-22, 2005). Kola SC RAS. Apatity, p. 236-238 (in Russian) [Соболева А.А., Кузенков Н.А., Удоратина О.В. Возраст цирконов из гранитов ядра Хобеизского гранито-гнейсового купола (ПриполярныйУрал) // Происхождение магматических пород: Материалы Международного Х Всероссийского петрографического совещания (20-22 июня 2005 г.). Апатиты: Кольский НЦ РАН, 2005. С. 236-238].

Soboleva A.A., Kuzenkov N.A., Udoratina O.V., Ivanov V.N., 2004b. High-Alumina Granites of S Type as Part of Collisional Granitoids of the Subpolar Urals. In: Geology and Mineral Resources of the European North-East of Russia. Proceedings of the Materials of the XIV Geological Congress of the Republic of Komi (April 13-16, 2004). Vol. II. Geoprint. Syktyvkar, p. 135-138 (in Russian) [Соболева A.A., Кузенков Н.А., Удоратина О.В., Иванов В.Н. Высокоглиноземистые граниты S-типа в составе коллизионных гранитоидов Приполярного Урала // Геология и минеральные ресурсы Европейского северо-востока России. Материалы XIV Геологического съезда Республики Коми (13-16 апреля 2004 г.). Сыктывкар: Геопринт, 2004. T. II. C. 135-138].

Soboleva A.A., Udoratina O.V., 2010. Pre-Ural Granitoids in the Urals. Bulletin of the Institute of Geology of the Komi Science Center of the Ural Branch of the Russian Academy of Sciences 9, 16-17 (in Russian) [Соболева A.A.,
Удоратина О.В. Доуральские гранитоиды на Урале // Вестник Института геологии Коми НЦ УрО РАН. 2010. № 9. C. 16-17].

Soboleva A.A., Udoratina O.V., Kuzenkov N.A., Larionov A.N., Varlamov D.A., 2005b. Svobodnensky Granite-Gneiss Massif (Subpolar Ural). In: L.V. Makhlaev (Ed.), Petrology and Mineralogy of the North Urals and Timan. Proceedings of the Institute of Geology of Komi Science Center Ural Branch of the Russian Academy of Sciences. Iss. 119. Syktyvkar, p. 65-96 (in Russian) [Соболева А.А., Удоратина О.В., Кузенков Н.А., Ларионов А.Н., Варламов Д.А. Свободненский гранито-гнейсовый масив (Приполярный Урал) // Петрология и минералогия Севера Урала и Тимана: Труды Института геологии Коми НЦ УрО РАН / Ред. Л.В. Махлаев. Сыктывкар, 2005. Вып. 119. С. 65-96].

Soboleva A.A., Udoratina O.V., Posokhov V.F., Kapitanova V.A., 2015. Isotopic Composition of Oxygen in Zircons from Granitoids of the North of the Urals. In: Petrography of Igneous and Metamorphic Rocks. Proceedings of the Materials of the XII All-Russian Petrographic Meeting (September 15-20, 2015). KSC RAS, Petrozavodsk, p. 253-255 (in Russian] [Соболева А.А., Удоратина О.В., Посохов В.Ф., Капитанова В.А. Изотопный состав кислорода в цирконах из гранитоидов севера Урала // Петрография магматических и метаморфических горных пород: Материалы XII Всероссийского петрографического совещания (15-20 сентября 2015 г.). Петрозаводск: КНЦ РАН, 2015. C. 253-255].

Sokerin M.Yu., Udoratina O.V., Kulikova K.V., Zharkov V.A., 2017. Granites of the Pioneer Mountains (Sablinsky Ridge, Subpolar Urals): The First U-Pb (SIMS) Data. In: Geodynamics, Substance, Oregenesis of the East European Platform and Its Folded Framing. Proceedings of the Materials All-Russian Scientific Conference with International Participation (September 26-28, 2017). IG Komi SC UB RAS, Syktyvkar, p. 201-203 (in Russian) [Сокерин М.Ю., Удоратина О.В., Куликова К.В., Жарков В.А. Граниты Пионергоры (Саблинский хребет, Приполярный Урал): первые $\mathrm{U}-\mathrm{Pb}$ (SIMS) данные // Геодинамика, вещество, рудогенез Восточно-Европейской платформы и ее складчатого обрамления: Материалы Всероссийской научной конференции с международным участием (26-28 сентября 2017 г.). Сыктывкар: ИГ Коми НЦ УрО РАН. 2017. C. 201-203].

State Geological Map of the Russian Federation, 2004. Series Polar-Ural. Scale 1:200000. Sheet Q-41-XI (Yeletsky). Explanatory Note. Moscow Branch of VSEGEI, Moscow, 217 p. (in Russian) [Государственная геологическая карта Российской Федерации. Масштаб 1:200000. Серия Полярно-Уральская. Лист Q-41-XI (Елецкий): Объяснительная записка. М.: МФ ВСЕГЕИ, 2004. 217 с.].

State Geological Map of the Russian Federation, 2006. Series Ural. Scale 1:1000000. Sheet P-40 (Severouralsk). Explanatory Note. VSEGEI Publishing House, Saint Petersburg, 332 p. (in Russian) [Государственная геологическая карта Российской Федерации. Масштаб 1:1000000. Серия Уральская. Лист Р-40 (Североуральск): Объяснительная записка. СПб.: Изд-во ВСЕГЕИ, 2006. 332 с.]. 
State Geological Map of the Russian Federation, 2007. Series Ural. Scale 1:1000000. Sheet Q-41 (Vorkuta). Explanatory Note. VSEGEI Publishing House, Saint Petersburg, 335 p. (in Russian) [Государственная геологическая карта Российской Федерации. Масштаб 1:1000000. Серия Уральская. Лист Q-41 (Воркута): Объяснительная записка. СПб.: Изд-во ВСЕГЕИ, 2007. 335 с.].

State Geological Map of the Russian Federation, 2010. Series Ural. Scale 1:1000000. Sheet Q-40 (Pechora). Explanatory Note. VSEGEI Publishing House, Saint Petersburg, 259 p. (in Russian) [Государственная геологическая карта Российской Федерации. Масштаб 1:1000000. Уральская серия. Лист Q-40 (Печора): Объяснительная записка. СПб.: Изд-во ВСЕГЕИ. 2010. 259 с.].

State Geological Map of the Russian Federation, 2013a. Series North Ural. Scale 1:200000. Sheet Q-41-XXV (Narodnaya). Explanatory Note. Moscow Branch of VSEGEI, Moscow, 259 p. (in Russian) [Государственная геологическая карта Российской Федерации. Масштаб 1:200000. Серия СевероУральская. Лист Q-41-XXV (г. Народная): Объяснительная записка. М.: МФ ВСЕГЕИ, 2013. 259 с.].

State Geological Map of the Russian Federation, 2013b. Series Polar-Ural. Scale 1:200000. Sheets Q-41-V, VI (Vorkuta). Explanatory Note. Moscow Branch of VSEGEI, Moscow, 262 p. (in Russian) [Государственная геологическая карта Российской Федерации. Масштаб 1:200000. Серия Полярно-Уральская. Лист Q-41-V, VI (Воркута): Объяснительная записка. М.: МФ ВСЕГЕИ, 2013. 262 с.].

State Geological Map of the Russian Federation, 2013c. Series West Siberian. Scale 1:1000000. Sheet Q-42 (Salekhard). Explanatory Note. VSEGEI Publishing House, Saint Petersburg, 396 p. (in Russian) [Государственная геологическая карта Российской Федерации. Масштаб 1:1000000. Западно-Сибирская серия. Лист Q-42 (Салехард): Объяснительная записка. СПб.: Изд-во ВСЕГЕИ, 2013. 396 с.].

State Geological Map of the Russian Federation, 2014a. Series Polar-Ural. Scale 1:200000. Sheet Q-41-XVI (Hordyus). Explanatory Note. VSEGEI Publishing House, Saint Petersburg, 256 p. (in Russian) [Государственная геологическая карта Российской Федерации. Масштаб 1:200000. Серия Полярно-Уральская. Лист Q-41-XVI (г. Хордъюс): Объяснительная записка. СПб.: Изд-во ВСЕГЕИ, 2014. 256 с.].

State Geological Map of the Russian Federation, 2014b. Series Polar-Ural. Scale 1:200000. Sheet Q-42-VII, VIII (Obskoy). Explanatory Note. VSEGEI Publishing House, Saint Petersburg, 446 p. (in Russian) [Государственная геологическая карта Российской Федерации. Масштаб 1:200000. Серия Полярно-Уральская. Лист Q-42-VII, VIII (Обской): Объяснительная записка. СПб.: Изд-во ВСЕГЕИ, 2014. 446 с.].

State Geological Map of the Russian Federation, 2016. Series North Ural. Scale 1:200000. Sheet P-40-XII (Kozhim-Iz). Explanatory Note. VSEGEI Publishing House, Saint Petersburg, 442 p. (in Russian) [Государственная геологическая карта Российской Федерации. Масштаб 1:200000. Серия Северо-Уральская. Лист P-40-XII (г. Кожим-Из): Объяснительная записка. СПб.: Изд-во ВСЕГЕИ, 2016. 442 с.].

State Geological Map of the Russian Federation, 2017a. Series North Ural. Scale 1:200000. Sheet P-40-XVIII (Lopsia).
Explanatory Note. Moscow Branch of VSEGEI, Moscow, $148 \mathrm{p}$. (in Russian) [Государственная геологическая карта Российской Федерации. Масштаб 1:200000. Серия СевероУральская. Лист P-40-XVIII (Лопсия): Объяснительная записка. М.: МФ ВСЕГЕИ, 2017. 148 с.].

State Geological Map of the Russian Federation, 2017b. Series North Ural. Scale 1:200000. Sheet Q-40-XXIX (Saber). Explanatory Note. VSEGEI Publishing House, Saint Petersburg, 312 p. (in Russian) [Государственная геологическая карта Российской Федерации. Масштаб 1:200000. Серия Северо-Уральская. Лист Q-40-XXIX (г. Сабля): Объяснительная записка. СПб: Изд-во ВСЕГЕИ, 2017. 312 с.].

State Geological Map of the Russian Federation, 2018a. Series North Ural. Scale 1:200000. Sheet P-40-VI (Telpos-Iz). Explanatory Note. VSEGEI Publishing House, Saint Petersburg, 216 p. (in Russian) [Государственная геологическая карта Российской Федерации. Масштаб 1:200000. Серия Северо-Уральская. Лист P-40-VI (г. Тельпос-Из): Объяснительная записка. СПб.: Изд-во ВСЕГЕИ, 2018. 216 с.].

State Geological Map of the Russian Federation, 2018b (in press). Series Middle Ural. Scale 1:200000. Sheet P-40XXIV (Chistop). Explanatory Note. VSEGEI Publishing House, Saint Petersburg, 371 p. (in Russian) [Государственная геологическая карта Российской Федерации. Масштаб 1:200000. Серия Средне-Уральская. Лист P-40-XXIV (Чистоп): Объяснительная записка. СПб.: Изд-во ВСЕГЕИ, 2018. 371 с. (в печати)].

State Geological Map of the Russian Federation, 2021a (in press). Series North Ural. Scale 1:200000. Sheet Q-40XXXVI (Lorsempey). Explanatory Note (in Russian) [Государственная геологическая карта Российской Федерации. Масштаб 1:200000. Серия Северо-Уральская. Лист Q-40-XXXVI (Лорцемпея): Объяснительная записка. 2021 (в печати)].

State Geological Map of the Russian Federation, 2021b (in press). Series Polar-Ural. Scale 1:200000. Sheet Q-41-IX, $\mathrm{X}$ (Sivomaskinsky). Explanatory Note. VSEGEI Publishing House, Saint Petersburg (in Russian) Государственная геологическая карта Российской Федерации. Масштаб 1:200000. Серия Полярно-Уральская. Лист Q-41-IX, X (Сивомаскинский): Объяснительная записка. СПб.: Изд-во ВСЕГЕИ, 2021 (в печати)].

Udoratina O.V., 2007. Rare Metal Complexes of the Polar Urals (Geochronology and Study of Inclusions in Zircons, Taykeuskoe Deposit). Geoprint, Syktyvkar, 28 p. (in Russian) [Удоратина О.В. Редкометалльные комплексы Полярного Урала (геохронология и исследование включений в цирконах, Тайкеуское месторождение). Сыктывкар: Геопринт, 2007. 28 с.].

Udoratina O.V., Andreichev V.L., Kalinin E.P., 2012a. Granitoids of the Khartes Massif (Subpolar Urals): Rb-Sr and Sm-Nd Data. In: Geodynamics, Ore Deposits and the Deep Structure of the Lithosphere. XV Readings in Memory of Academician A.N. Zavaritsky. Proceedings of the All-Russian Scientific Conference with International Participation. Publishing House of IGG UB RAS, Ekaterinburg, p. 256-257 (in Russian) [Удоратина О.В., Андреичев В.Л., Калинин Е.П. Гранитоиды Хартесского массива (Приполярный Урал): 
$\mathrm{Rb}-\mathrm{Sr}$ и Sm-Nd данные // Геодинамика, рудные месторождения и глубинное строение литосферы: XV Чтения памяти академика А.Н. Заварицкого: Материалы Всероссийской научной конференции с международным участием. Екатеринбург: ИГГ УрО РАН, 2012. C. 256-257].

Udoratina O.V., Andreichev V.L., Kapitanova V.A., Coble M.A., Geng Ts., 2017. Granites of the Manhambov, Ilyaiz Massifs and Rare-Metal Rocks of the Manhambov Massif (Northern Urals). In: Granites and Earth Evolution: Mantle and Bark in Granite Formation. Proceedings of the Materials of the III International Geological Conference (August 28-31, 2012). IGG UB RAS, Ekaterinburg, p. 298-300 (in Russian) [Удоратина О.В., Андреичев В.Л., Капитанова В.А., Кобл М.А., Ген Ц. Граниты Маньхамбовского, Ильяизского массивов и редкометалльные породы Маньхамбовского массива (Северный Урал) // Граниты и эволюция Земли: мантия и кора в гранитообразовании: Материалы III международной геологической конференции (2831 августа 2017 г.). Екатеринбург: ИГГ УрО РАН, 2017. C. 298-300].

Udoratina O.V., Andreichev V.L., Kapitanova V.A., Larionov A.N., 2015a. Rare-Metal Granitoids (Neudachnoye Deposit, Polar Urals). Otechestvennaya Geologiya 4, 9-16 (in Russian) [Удоратина 0.В., Андреичев В.Л., Капитанова В.А., Ларионов А.Н. Редкометалльные гранитоиды (месторождение Неудачное, Полярный Урал) // Отечественная геология. 2015. № 4. С. 9-16].

Udoratina O.V., Andreichev V.L., Larionov A.N., Tolmacheva E.V., 2012b. Granitoids of the Ilyaiz Massif (Northern Urals): New Geochronological Data. In: Geodynamics, Ore Deposits and the Deep Structure of the Lithosphere. XV Readings in Memory of Academician A.N. Zavaritsky. Proceedings of the Materials of the All-Russian Scientific Conference with International Participation (September 1114, 2012). Publishing House of IGG UB RAS, Ekaterinburg, p. 258-259 (in Russian) [Удоратина О.В., Андреичев В.Л., Ларионов А.Н., Толмачева Е.В. Гранитоиды Ильяизского массива (Северный Урал): новые геохронологические данные // XV Чтения памяти академика А.Н. Заварицкого: Геодинамика, рудные месторождения и глубинное строение литосферы: Материалы Всероссийской научной конференции с международным участием (11-14 сентября 2012 г.). Екатеринбург: ИГГ УрО РАН, 2012. C. 258-259].

Udoratina O.V., Coble M.A., Shuyskiy A.S., Kapitanova V.A., 2019. Granitoids of the Nyarta Block (Subpolar Urals): New Data. Vestnik IG Komi SC UB RAS 9, 23-32. https://doi.org/ 10.19110/2221-1381-2019-9-23-32.

Udoratina O.V., Kalinin E.P., Andreichev V.L., Kapitanova V.A., Ronkin Yu.L., Savatenkov V.M., 2014a. Torgovsk Keftalyk Granitoid Massif (Subpolar Urals): Isotopic Geochemical Data. Bulletin of Komi SC UB RAS 3 (19), 93-104 (in Russian) [Удоратина О.В., Калинин Е.П., Андреичев В.Л., Капитанова В.А., Ронкин Ю.Л., Саватенков В.М. Гранитоиды Торговско-Кефталыкского массива (Приполярный Урал): изотопно-геохимические данные // Известия Коми НЦ УрО РАН. 2014. Вып. 3. № 19. С. 93-104].
Udoratina O.V., Kapitanova V.A., Varlamov D.A., 2014b. Rale Metal Granitoids (Kulemshor, Subpolar Urals). Bulletin of Komi SC UB RAS 1 (17), 57-70 (in Russian) [Удоратина О.В., Капитанова В.А., Варламов Д.А. Редкометалльные гранитоиды (Кулемшор, Приполярный Урал) // Известия Коми НЦ УрО РАН. 2014. Вып. 1. № 17. С. 57-70].

Udoratina O.V., Kudryashov N.M., 2017. Zircons of Complex (Nb-Ta, Y and REE, Zr, Less Often Be) Ores of the Taykey Deposit (Polar Urals): U-Pb ID TIMS Data. In: Main Problems in the Study of Endogenous Ore Deposits: New Horizons. Proceedings of the Materials of the All-Russian Conference Dedicated to the 120th Birthday of the Outstanding Russian Scientist Academician A.G. Betekhtin (November 20-22, 2017). IGEM RAS, Moscow, p. 62-64 (in Russian) [Удоратина О.В., Кудряшов Н.М. Цирконы комплексных (Nb-Ta, $\mathrm{Y}$ и REE, Zr, реже Be) руд месторождения Тайкеу (Полярный Урал): U-Pb ID TIMS данные // Основные проблемы в учении об эндогенных рудных месторождениях: новые горизонты: Материалы Всероссийской конференции, посвященной 120 -летию со дня рождения выдающегося российского ученого академика А.Г. Бетехтина (20-22 ноября 2017 г.). М.: ИГЕМ РАН, 2017. C. 62-64].

Udoratina O.V., Kudryashov N.M., 2018. Rare-Metal Rocks of the Ust-Mramornoye Deposit (Polar Urals): U-Pb ID TIMS Data. In: Methods and Geological Results of the Study of Isotopic Geochronometric Systems of Minerals and Rocks. Proceedings of the Materials of the 7th Russian Conference on Isotope Geochronology (June 5-7, 2018). IGEM RAS, Moscow, p. 363-366 (in Russian) [Удоратина O.В., Кудряшов Н.М. Редкометалльные породы месторождения Усть-Мраморное (Полярный Урал): U-Pb ID TIMS данные // Методы и геологические результаты изучения изотопных геохронометрических систем минералов и пород: Материалы 7-й Российской конференции по изотопной геохронологии (5-7 июня 2018 г.). М.: ИГЕМ РАН, 2018. C. 363-366].

Udoratina O.V., Kuznetsov N.B., 2007. Sobsky Plagiogranitoid Complex of the Polar Urals. Bulletin of Moscow Society of Naturalists. Geological Section 82 (3), 49-59 (in Russian) [Удоратина O.В., Кузнецов Н.Б. Собский плагиогранитоидный комплекс Полярного Урала // Бюллетень МОИП. Отдел геологический. 2007. Т. 82. Вып. 3. C. 49-59].

Udoratina O.V., Kuznetsov N.B., Matukov D.I., 2005. The Age of Granitoids of the Yanaslor Massif (Polar Urals): U-Pb Data. In: Petrology of Igneous and Metamorphic Complexes. Proceedings of the Materials of the All-Russian Petrographic Conference (November 24-26, 2016). Iss. 5. Vol. 1. Publishing House of Tomsk CSTI, Tomsk, p. 135-142 (in Russian) [Удоратина О.В., Кузнецов Н.Б., Матуков Д.И. Возраст гранитоидов Янаслорского массива (Полярный Урал): $\mathrm{U}-\mathrm{Pb}$ данные // Петрология магматических и метаморфических комплексов: Материалы Всероссийской петрографической конференции (24-26 ноября 2005 г.). Томск: ЦНТИ, 2005. Вып. 5. Т. 1. С. 135-142].

Udoratina O.V., Salnikova E.B., Savatenkov V.M., Larionov A.N., Sitnikova M.A., 2015b. Dating of Ore and Accessory 
Minerals of theLongyugugan Rare-Metal Complex (Polar Ural): New Data. In: Isotopic Dating of Geological Processes: New Results, Approaches and Prospects. Proceedings of the VI Russian Conference on Isotope Geochronology (June 2-5, 2015). Sprinter, Saint Petersburg, p. 314-315 (in Russian) [Удоратина О.В., Сальникова Е.Б., Саватенков В.М., Ларионов А.Н., Ситникова М.А. Датирование рудных и акцессорных минералов лонготъюганского редкометалльного комплекса (Полярный Урал): новые данные // Изотопное датирование геологических процессов: новые результаты, подходы и перспективы: Материалы VI Российской конференции по изотопной геохронологии (2-5 июня 2015 г.). СПб.: Sprinter, 2015. C. 314-315].

Udoratina O.V., Salnikova E.B., Yakovleva S.Z., Fedoseenko A.M., Plotkina Yu.V., 2009. The Age of Ore-Bearing Granites of the Longyugansk Rare-Metal Deposit (Polar Ural): $\mathrm{U}-\mathrm{Pb}$ Results of Geochronological Studies. In: Isotopic Systems and Time of Geological Processes. Proceedings of the Materials IV Russian Conference in Isotope Geochronology (June 2-4, 2009). Vol. 2. Katalkina, Saint Petersburg, p. 227228 (in Russian) [Удоратина О.В., Сальникова Е.Б., Яковлева С.З., Федосеенко А.М., Плоткина Ю.В. Возраст рудоносных гранитов Лонготъюганского редкометалльного месторождения (Полярный Урал): результаты U-Pb геохронологических исследований // Изотопные системы и время геологических процессов: Материалы IV Российской конференции по изотопной геохронологии (2-4 июня 2009 г.). СПб: ИП Каталкина, 2009. Т. II. C. 227-228].

Udoratina O.V., Shatagin K.N., Kuznetsov N.B., 2003. Sobsky Plagiogranitoid Complex of the Polar Urals: The First Sm-Nd Isotope Data. In: Lithosphere Structure and Geodynamics. Proceedings of the Materials of the XX Youth Conference (April 21-26, 2003). IEC SB RAS, Irkutsk, p. 189-191 (in Russian) [Удоратина О.В., Шатагин К.Н., Кузнецов Н.Б. Собский плагиогранитоидный комплекс Полярного Урала: первые Sm-Nd изотопные данные // Строение литосферы и геодинамика: Материалы XX молодежной конференции (21-26 апреля 2003 г.). Иркутск: ИЗК СО PAH, 2003. С. 189-191].

Udoratina O.V., Shuyskiy A.S., Kapitanova V.A., 2020. Granitoids of the Kozhim Massif (Subpolar Urals): U-Pb, Lu-Hf Data. Bulletin of Komi SC UB RAS Earth Sciences Series 1 (41), 96-105 (in Russian) [Удоратина O.В., Шуйский А.C., Капитанова В.А. Гранитоиды Кожимского массива (Приполярный Урал): U-Pb, Lu-Hf данные // Известия Коми научного центра УрО РАН серия «Науки о Земле». 2020. № 1 (41). C. 96-105]. https://doi.org/10.19110/1994-56 55-2020-1-96-105.

Udoratina O.V., Soboleva A.A., Kuzenkov N.A., Rodionov N.V., Presnyakov S.L., 2006. Age of Granitoids in the Man'khambo and Il'yaiz Plutons, the Northern Urals: U-Pb Data. Doklady Earth Sciences 407 (2), 284-289. https: // doi.org/10.1134/S1028334X06020309.

Udoratina O.V., Varlamov D.A., Shevchuk S.S., 2015c. Composition of Mineral-Forming Environment of Rare Metal Kulemshor Mineralization (Subpolar Urals). In: Alkaline Magmatism of the Earth and Related Strategic Metal Deposits. Proceedings of the XXXII International Conference (August 7-14, 2015). Apatity, p. 136-137.

Valley J.W., Kinny P.D., Schulze D.J., Spicuzza M.J., 1998. Zircon Megacrysts from Kimberlite: Oxigen Isotope Variability among Mantle Melts. Contributions to Mineralogy and Petrology 133, 1-11. https://doi.org/10.1007/s0041 00050432.

Vodolazskaya V.P., Lvov B.K., Larin A.O., 2011. Once Again about the Age and Genesis of Granitoids of the Subpolar Urals. Otechestvennaya Geologiya 3, 71-79 (in Russian) [Boдолазская В.П., Львов Б.К., Ларин А.О. Еще раз о возрасте и генезисе гранитоидов Приполярного Урала // Отечественная геология. 2011. № 3. С. 71-79].

Whalen J.B., Currie K.L., Chappell B.W., 1987. A-Type Granites: Geochemical Characteristics, Discrimination and Petrogenesis. Contributions to Mineralogy and Petrology 95, 407-419. https://doi.org/10.1007/BF00402202. 